\title{
Utilization of Cyanoacetohydrazide and Oxadiazolyl Acetonitrile in the Synthesis of Some New Cytotoxic Heterocyclic Compounds
}

\author{
Soheir A. Shaker ${ }^{\dagger}$ and Magda I. Marzouk ${ }^{*}{ }^{\dagger}$ \\ Chemistry Department, Faculty of Science, Ain Shams University, Abassia 11566, Cairo, Egypt; \\ soheirshaker@yahoo.com \\ * Correspondence: magda_marzouk@sci.asu.edu.eg; Tel.: +20-2-0122-330-9974 \\ $\dagger$ All the authors contributed equally to this work. \\ Academic Editor: Derek J. McPhee \\ Received: 15 December 2015 ; Accepted: 22 January 2016 ; Published: 29 January 2016
}

\begin{abstract}
A (pyridazinyl)acetate derivative was reacted with thiosemicarbazide and hydrazine hydrate to yield spiropyridazinone and acetohydrazide derivatives, respectively. The acetohydrazide derivative was used as a starting material for synthesizing some new heterocyclic compounds such as oxoindolinylidene, dimethylpyrazolyl, methylpyrazolyl, oxopyrazolyl, cyanoacetylacetohydrazide and oxadiazolylacetonitrile derivatives. The behavior of the cyanoacetylacetohydrazide and oxadiazolylacetonitrile derivatives towards nitrogen and carbon nucleophiles was investigated. The assigned structures of the prepared compounds were elucidated by spectral methods (IR, ${ }^{1} \mathrm{H}-\mathrm{NMR}$ ${ }^{13} \mathrm{C}$-NMR and mass spectroscopy). Some of the newly prepared compounds were tested in vitro against a panel of four human tumor cell lines, namely hepatocellular carcinoma (liver) HePG-2, colon cancer HCT-116, human prostate cancer PC3, and mammary gland breast MCF-7. Also they were tested as antioxidants. Almost all of the tested compounds showed satisfactory activity.
\end{abstract}

Keywords: cyanoacetohydrazide; oxadiazolylacetonitrile; pyridazinone

\section{Introduction}

Living organisms have difficulties in the construction of N-N bonds that limits the natural abundance of compounds having such bonds. Pyridazinone derivatives, a class of compounds containing the $\mathrm{N}-\mathrm{N}$ bond, exhibit a wide range of pharmacological activity [1], including analgesic, antidepressant, anti-inflammatory [2-6], antimicrobial [7,8] as well as herbicidal activities [9]. There are numerous reports available in the literature, which indicate the potential anticancer effects of pyridazinones. 6-(4-Hydroxy-2-methylphenyl)-2-( $p$-sulfamylphenyl)-4,5-dihydropyridazine-3(2H)-one [10] showed high activity against HL-60 (TB) (leukemia), SR (leukemia), NCIH522 (non-small-cell lung cancer), and BT-549 (breast cancer), the $p$-methoxydichloropyridazone [11] displayed a good inhibition of tumour growth in mice for the resistant MAC16 cell line. Some diphenylpyridazine derivatives [12] (particularly NSC 351478) were effective in the treatment of P388 leukemia in mice. The substituents at position 2 of the pyridazinone ring do not fall into a clear pattern; alterations at this position can have major effects on the activity of the resulting compounds. More specific was the effect of chlorinating the phenyl rings. Position $4^{\prime}$ seems most important, but a second chlorine at position $3^{\prime}$ further enhances inhibition of microtubule assembly in vitro (Figure 1). Further investigations will be required for a more detailed evaluation of anticancer pyridazine compounds with different molecular mechanisms for enhancing anticancer activities and minimizing toxicities. For these reasons we have introduced hydrazide and 1,3,4-oxadiazole moieties to the pyridazine ring to enhance the cytotoxic activity. 


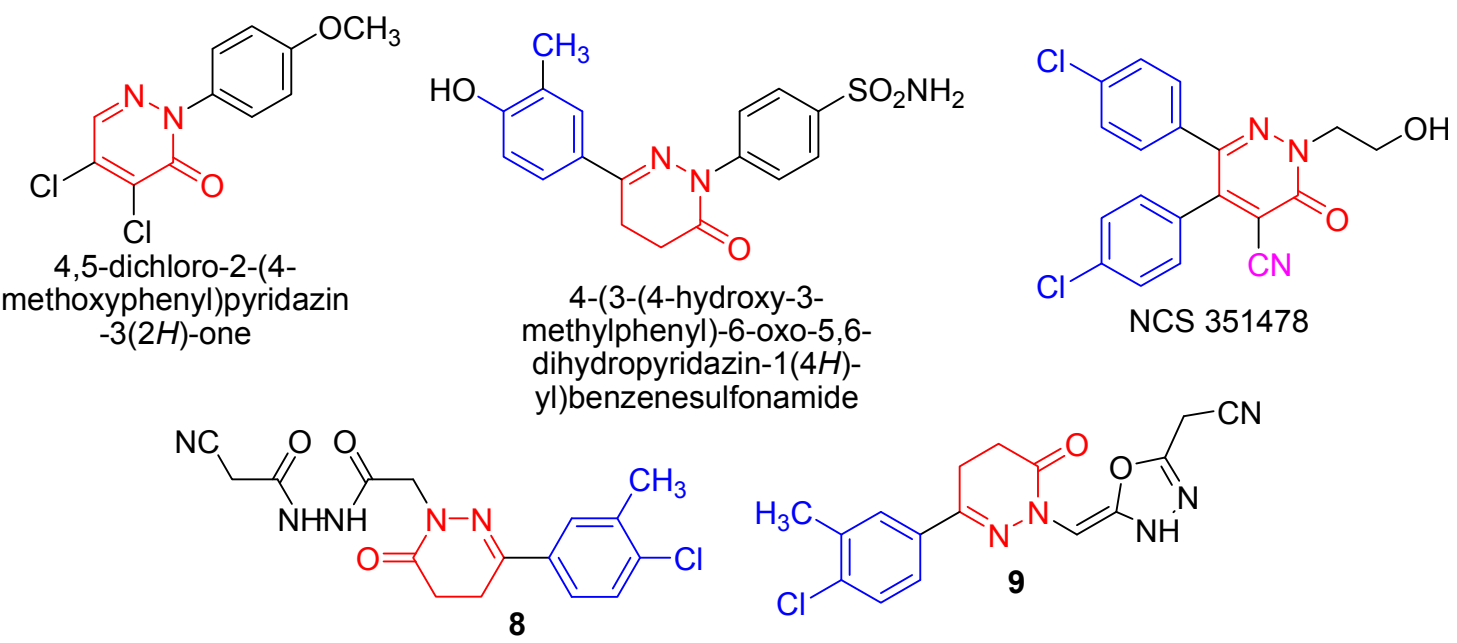

Figure 1. Anticancer pyridazine derivatives.

Hydrazides are very useful starting materials for the construction of several heterocyclic compounds such as 1,3,4-oxadiazoles [13], 1,3-thiazoles [14], 1,3,4-thiadiazoles [15], 1,2,4-triazoles [16], 1,2,4-triazolo[3,4-b]-1,3,4-thiadiazoles [17] 1,2,4-triazolo[3,4-b]-1,3,4-thiadiazines [18], pyrroles [19] and pyrazoles [20]. The common practical route for hydrazide synthesis is the treatment of esters with hydrazine hydrate. They are also synthesized by the reaction of hydrazine hydrate or its derivatives with carboxylic acids and acyl halides [21]. Hydrazides including $\alpha, \beta$-unsaturated acids were synthesized from the reaction of activated esters and/or amides with hydrazines [22]. Hydrazide oligonucleotides were also synthesized [21]. The use of microwave irradiation is a facile way of preparing hydrazides by solvent-free reactions of acid derivatives with hydrazine hydrate [23-25]. Among several commercially available substituted hydrazines, cyanoacetic acid hydrazide has received the most attention [26,27]. Cyanoacetic acid hydrazide was obtained by the addition of hydrazine hydrate to ethyl cyanoacetate in methanolic ice-cooled solution [28]. Cyanoacetic acid hydrazide is a versatile and convenient intermediate for the synthesis of wide variety of heterocyclic compounds. This substrate can act as an ambident nucleophile, that is, as both a $\mathrm{N}$ - and $\mathrm{C}$-nucleophile. The reactions of cyanoacetic acid hydrazide with numerous reactants (nucleophiles and electrophiles) are used in the synthesis of a variety of polyfunctional heterocyclic compounds with pharmacological interest.

1,3,4-Oxadiazoles constitute an important family of heterocyclic compounds as they have attracted significant interest in medicinal chemistry, pesticide chemistry and polymer science. The 1,3,4-oxadiazoles have been found to exhibit diverse biological activities such as antimicrobial [29-33], antitubercular [34], antioxidant [35], antimalarial [36], analgesic [37], anti-inflammatory [38,39], anticonvulsant [40], hypoglycemic [41] activities, as well as other biological properties such as genotoxic [42] and lipid peroxidation inhibitory activities [43]. Two examples of compounds containing the 1,3,4-oxadiazole ring used in clinical medicine are raltegravir, an antiretroviral drug [44] and zibotentan, an anticancer agent [45] (Figure 2). Also N-(5-(cyano(4-methyl-3-phenylthiazol-2(3H)ylidene)methyl)-1,3,4-oxadiazol-2-yl)benzamide which contains the 1,3,4-oxadiazole ring and the nitrile group showed antitumor activity [46].

1,3,4-Oxadiazole derivatives were synthesized via the reaction of hydrazide derivatives using different reagents such as $\mathrm{CS}_{2}$ [47], $\mathrm{POCl}_{3}$ /aromatic carboxylic acid [48], thionyl chloride [49-51], triphenylphosphine oxide, [52] silica-supported dichlorophosphate [53] and $\mathrm{ZrCl}_{4}$ [54]. The syntheses of 1,3,4-oxadiazoles via the Huisgen reaction $[55,56]$ is a less popular methodology than the methods mentioned above. On the other hand, Efimova et al. reported [57] the synthesis of 1,3,4-oxadiazole derivatives via the acylation of tetrazoles with acetic and benzoic anhydrides. The yield of the products obtained by these methods ranged from $73 \%-96 \%$. 
In the light of these facts, and as a continuation of our efforts towards synthesizing biologically active heterocyclic compounds especially those with antitumor activity [58-62], we planned to synthesize new hydrazide and 1,3,4-oxadiazole derivatives in the hope that new antitumor agents might be discovered.<smiles>Cc1nnc(C(=O)NC(C)(C)c2nc(C(=O)NCc3ccc(F)cc3)c(O)c(=O)n2C)o1</smiles><smiles>COc1nc(C)cnc1NS(=O)(=O)c1cccnc1-c1ccc(-c2nnco2)cc1</smiles><smiles>CC1=CS/C(=C(/C#N)c2nnc(NC(=O)c3ccccc3)o2)N1c1ccccc1</smiles><smiles>N#CCC(=O)NNC(=O)CN1N=C([Al])CCC1=O</smiles><smiles>N#CCC1=NN/C(=C/N2N=C([Al])CCC2=O)O1</smiles>

$\mathrm{N}$-(5-(cyano(4-methyl-3-phenylthiazol-2(3H)ylidene)methyl)-1,3,4-oxadiazol-2-yl)benzamide heptacellular carinoma HepG2 $\left(\mathrm{IC}_{50}=12.4 \mu \mathrm{g} / \mathrm{mL}\right)$

Figure 2. 1,3,4-Oxadiazole drugs and compounds 8 and 9.

\section{Results and Discussion}

\subsection{Chemistry}

The ester derivative $\mathbf{1}$ was reacted with nitrogen nucleophiles such as thiosemicabazide and hydrazine hydrate to yield the spiro compound 2 [63] and the acetohydrazide derivative 3, respectively (Scheme 1). The IR spectrum of compound 2 showed bands corresponding to $\mathrm{NH}$ and $\mathrm{C}=\mathrm{O}$ groups at 3263 and $1741 \mathrm{~cm}^{-1}$, respectively. The ${ }^{1} \mathrm{H}-\mathrm{NMR}$ spectrum is in accord with the proposed structure, as it showed signals for $\mathrm{NH}$, aliphatic and aromatic protons, four $\mathrm{CH}_{2}$ and two $\mathrm{CH}_{3}$ moieties at $\delta 8.58$, $7.40-7.77,4.36,4.14,2.98,2.56,2.37$ and $1.20 \mathrm{ppm}$, respectively. The presence of the triplet and the quartet signals at $\delta 1.20$ and $4.14 \mathrm{ppm}$, respectively, in its ${ }^{1} \mathrm{H}-\mathrm{NMR}$ spectrum and also the presence of signals at $\delta 14.03$ and $60.76 \mathrm{ppm}$ in its ${ }^{13} \mathrm{C}$-NMR spectrum indicated the presence of the ester group which proved that the reaction occurred at the carbonyl carbon of the ring rather than that of the ester. The ${ }^{13} \mathrm{C}$-NMR spectrum showed a signal at $\delta 94.28 \mathrm{ppm}$ which supported the spiro structure. Further evidence was gained from the mass spectrum as it showed the correct molecular ion peak at $m / z 379$, in addition to some other important fragment peaks.

The formation [63] of the spiro derivative 2 could be explained on the basis of nucleophilic attack of the nitrogen atom of the thiosemicarbazide molecule on the ring carbonyl carbon atom followed by ring closure through the elimination of water and dehydrogenation.

The acetohydrazide 3 was reacted with different carbon nucleophiles to yield some new interesting heterocyclic compounds. It was reacted with cyclic and acyclic diones such as isatin and acetylacetone to yield the corresponding oxoindolinylidene 4 and the pyrazolyl 5 derivatives, respectively. The structures of compounds 4 and 5 were confirmed by their analytical and spectroscopic data. The IR spectrum of compound 4 showed broad band at $3173 \mathrm{~cm}^{-1}$ assigned to N-H and bands at $1642-1695 \mathrm{~cm}^{-1}$ assigned to $3 \mathrm{C}=\mathrm{O}$, and a band at $1619 \mathrm{~cm}^{-1}$ for $\mathrm{C}=\mathrm{N}$. The lower absorption value for the indolyl carbonyl suggests the existence of compound 4 as its chelated form 4 a as shown (Scheme 1). Inspection of the ${ }^{1} \mathrm{H}-\mathrm{NMR}$ spectrum of compound 4 showed the existence of three exchangeable broad 
singlet signals in the downfield region at $\delta 11.21,12.57$ and 13.21 corresponding to $2 \mathrm{NH}$ and $\mathrm{OH}$ protons, this suggests the existence of compound 4 in deuterated dimethyl sulfoxide solution as an equilibrium mixtures of $\mathbf{4 a}, \mathbf{b}$ in the ratio of $72: 27$ as shown (Scheme 1). Compound 4 is stabilized by conjugation and intramolecular hydrogen bonding. Further evidence was gained from mass spectrum as it showed the correct molecular ion peak at $m / z 423$ beside some other important peaks. The ${ }^{13} \mathrm{C}-\mathrm{NMR}$ spectrum was also in accordance with the proposed structure.

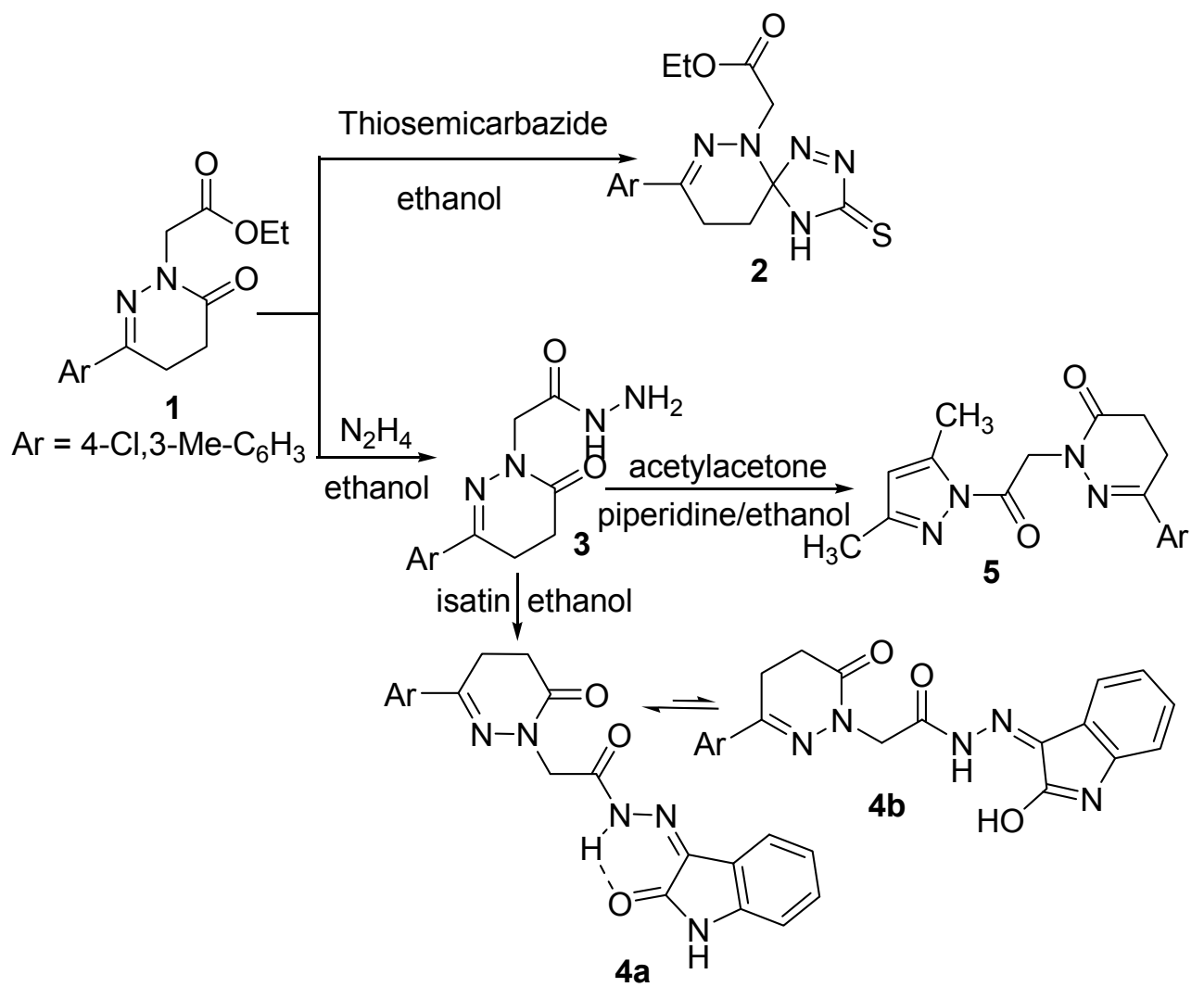

Scheme 1. Synthetic route for the preparation of compounds 2-5.

The IR spectrum of compound 5 showed two bands attributed to $2 \mathrm{C}=\mathrm{O}$ at 1731 and $1681 \mathrm{~cm}^{-1}$, respectively. The ${ }^{1} \mathrm{H}-\mathrm{NMR}$ spectrum of compound 5 showed signals at 7.40-7.78, 6.25, 5.22, 3.05, $2.61 \mathrm{ppm}$ corresponding to aromatic protons, $=\mathrm{CH}$ and three $\mathrm{CH}_{2}$, respectively. The presence of signals at $2.49,2.45$ and $2.21 \mathrm{ppm}$ also indicated the presence of three $\mathrm{CH}_{3}$ groups. In addition, the ${ }^{1} \mathrm{H}-\mathrm{NMR}$ spectrum was devoid of any signals corresponding to $\mathrm{NH}$ and $\mathrm{NH}_{2}$ protons which are in accord with the proposed structure. The ${ }^{13} \mathrm{C}-\mathrm{NMR}$ spectrum exhibited signals at $\delta 13.45,13.63$ and $19.54 \mathrm{ppm}$ due to the presence of three $\mathrm{CH}_{3}$ groups. The mass spectrum of compound 5 showed the molecular ion peak at $m / z 358$, which is coincident with its molecular weight.

The reaction of the acetohydrazide 3 with ethyl acetoacetate and ethyl benzoylacetate yielded the corresponding pyrazolone derivatives 6 and 7, respectively (Scheme 2). The reactions occurred at the ketonic carbonyl followed by 5-exo-trig ring closure. The structures of compounds 6 and 7 were confirmed by analytical and spectroscopic data. The IR spectrum of compound 6 showed bands for $\mathrm{NH}$ and $\mathrm{C}=\mathrm{O}$ groups at 3195, 1675, 1661 and $1642 \mathrm{~cm}^{-1}$, respectively. Further evidence for the structure of compound 6 was gained from its ${ }^{1} \mathrm{H}-\mathrm{NMR}$ spectrum which showed signals at 9.98, 7.43-7.75, 4.41, 3.00, 2.58, 2.72 and 2.35 ppm attributed to $\mathrm{OH}$, aromatic protons, three $\mathrm{CH}_{2}$ and two $\mathrm{CH}_{3}$ groups, respectively. The higher $\delta$ signal at $9.98 \mathrm{ppm}$ for the exchangeable broad singlet and the presence of a signal at $\delta 135.71 \mathrm{ppm}$ in its NMR $\left({ }^{1} \mathrm{H}\right.$ and $\left.{ }^{13} \mathrm{C}\right)$ spectra are good evidence for the existence of compound $\mathbf{6}$ in deuterated DMSO solution as its hydroxypyrazole $\mathbf{6 b}$. Meanwhile, the IR spectrum 
of compound 7 showed bands for $\mathrm{NH}$ and $\mathrm{C}=\mathrm{O}$ groups at 3312,1669 and $1648 \mathrm{~cm}^{-1}$, respectively. The ${ }^{1} \mathrm{H}-\mathrm{NMR}$ spectrum of compound 7 showed signals at 9.09, 7.40-7.75, 4.31, 4.24, 3.01, 2.55, and $2.36 \mathrm{ppm}$ attributed to $\mathrm{OH}$, aromatic protons, $\mathrm{CH}_{2}, \mathrm{NH}$, two $\mathrm{CH}_{2}$ and a $\mathrm{CH}_{3}$, respectively. However, the appearance of two exchangeable broad singlet signals, one in the upfield region and the second in the downfield region in the ratio of 35:65 suggests the existence of compound 7 as an equilibrium mixture of $7 \mathbf{a}$ and $\mathbf{7 b}$ (Scheme 2). The ${ }^{13} \mathrm{C}$-NMR spectrum was also in accordance with the proposed structure. Further evidence for compounds $\mathbf{6}$ and 7 was gained from mass spectra, as they showed the correct molecular ion peaks for compounds 6 and 7 at $m / z 308$ and 422, respectively, beside some other important peaks.

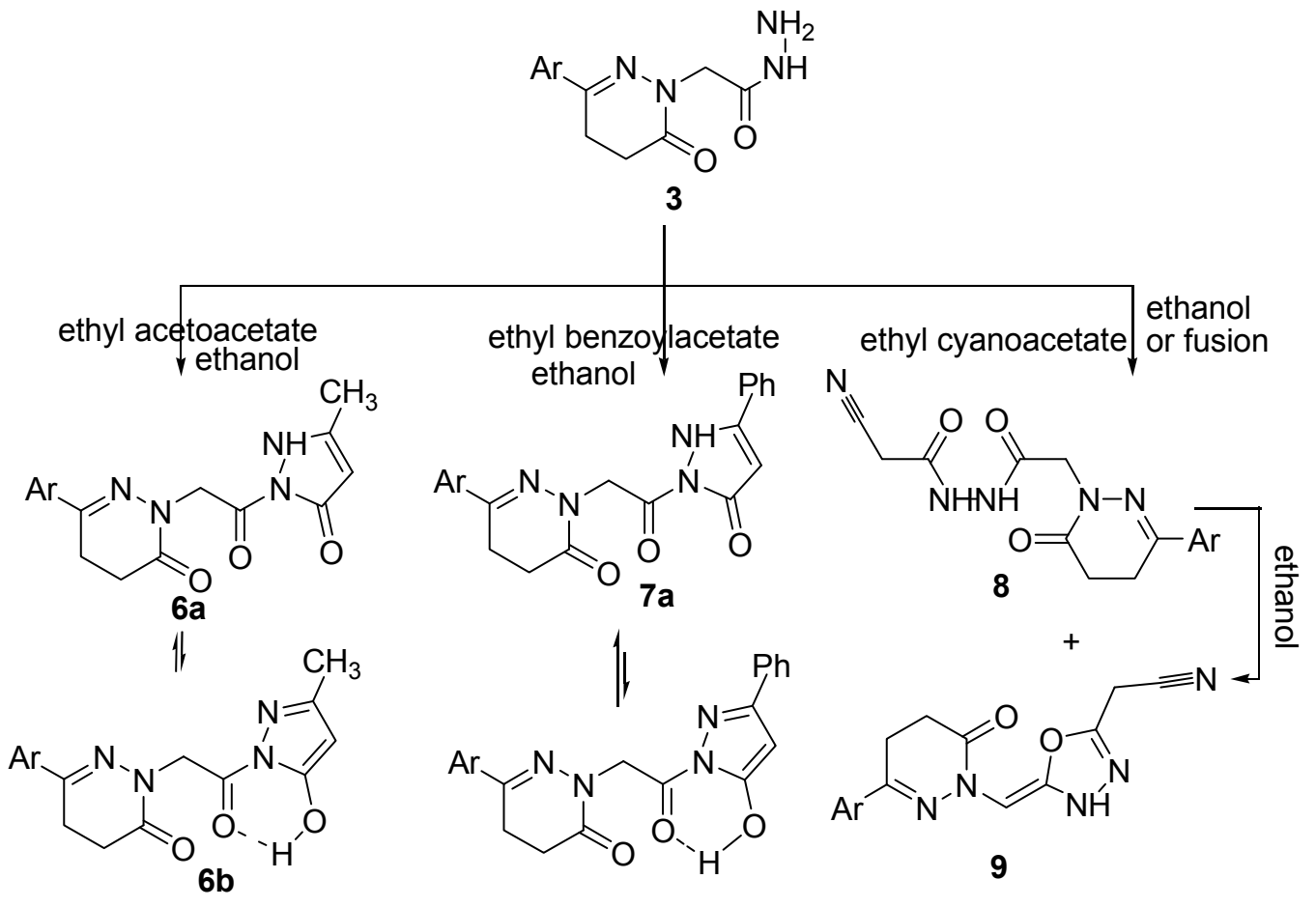

Scheme 2. Synthetic route for the preparation of compounds 6-9.

The cyanoacetylacetohydrazide $\mathbf{8}$ was formed as a sole product upon refluxing equimolar amounts of an alcoholic solution of the acetohydrazide 3 with ethyl cyanoacetate, while fusion of the acetohydrazide 3 with excess of ethyl cyanoacetate yielded both the open chain product cyanoacetyl acetohydrazide derivative $\mathbf{8}$ and the cyclic oxadiazolyl acetonitrile derivative product $\mathbf{9}$. The structures of these compounds were confirmed by analytical and spectroscopic data. The IR spectra of compounds 8 and 9 revealed the existence of the cyano groups at 2212 and $2206 \mathrm{~cm}^{-1}$, respectively. The ${ }^{1} \mathrm{H}-\mathrm{NMR}$ spectrum of compound 8 showed a singlet signal corresponding to the $\mathrm{CH}_{2} \mathrm{CN}$ group at $\delta 4.33 \mathrm{ppm}$, and two singlets at $\delta 9.44$ and $9.89 \mathrm{ppm}$ corresponding to two $\mathrm{NH}$ protons. The ${ }^{1} \mathrm{H}-\mathrm{NMR}$ spectrum of compound 9 meanwhile showed a singlet signal for the $\mathrm{CH}_{2} \mathrm{CN}$ group at $\delta 4.41 \mathrm{ppm}$, a multiplet for $\mathrm{HC}=\mathrm{C}$ and aromatic protons at $\delta 7.38-7.75 \mathrm{ppm}$ and a singlet for one $\mathrm{NH}$ at $\delta 9.99 \mathrm{ppm}$. The ${ }^{13} \mathrm{C}-\mathrm{NMR}$ spectrum of compound 9 showed signals at $\delta 19.60,60.75,120.14$ and 172.18 ppm corresponding to $\mathrm{CH}_{2}, \mathrm{HC}=\mathrm{C}, \mathrm{C} \equiv \mathrm{N}$ and $\mathrm{HC}=\underline{\mathrm{C}}$, respectively. Further evidence was gained from the mass spectra of compounds 8 and $\mathbf{9}$, as they showed the correct molecular ion peaks at $m / z 361$ and 343, respectively, in addition some other important fragmentation peaks. The presence of $\mathrm{C} \equiv \mathrm{N}$ in the IR as well as ${ }^{13} \mathrm{C}-\mathrm{NMR}$ spectra and also the presence of the $\mathrm{CH}_{2} \mathrm{CN}$ in the NMR $\left({ }^{1} \mathrm{H}\right.$ and $\left.{ }^{13} \mathrm{C}\right)$ spectra supported the proposed structures of compounds 8 and $\mathbf{9}$. Chemical proof for the structure of compound $\mathbf{9}$ was gained by heating compound 8 in ethanol to afford the oxadiazolyl acetonitrile derivative 9 . Compound $\mathbf{8}$ was formed via Claisen condensation of the terminal amino group with ester group of 
the ethyl cyanoacetate, while compound $\mathbf{9}$ is formed from compound $\mathbf{8}$ through keto-enol tautomerism followed by cyclization. Further evidence for the structures of compounds $\mathbf{8}$ and $\mathbf{9}$ were obtained through studying their chemical reactivity towards some chemical reagents.

Compounds with an activated methylene group react as carbanions in the presence of a base with the electrophilic carbon disulfide to give dithiocarboxylates which can be converted to ketene dithioacetals on treatment with an excess of the alkylating reagent. Thus, stirring of the cyanoacetyl acetohydrazide 8 and the oxadiazolyl acetonitrile 9 with carbon disulfide in the presence of $\mathrm{KOH}$ in DMF followed by the addition in situ of dimethyl sulfate afforded compounds $\mathbf{1 0}$ and $\mathbf{1 1}$ via the intermediates $(\mathrm{A} 1,2)$ (Scheme 3).

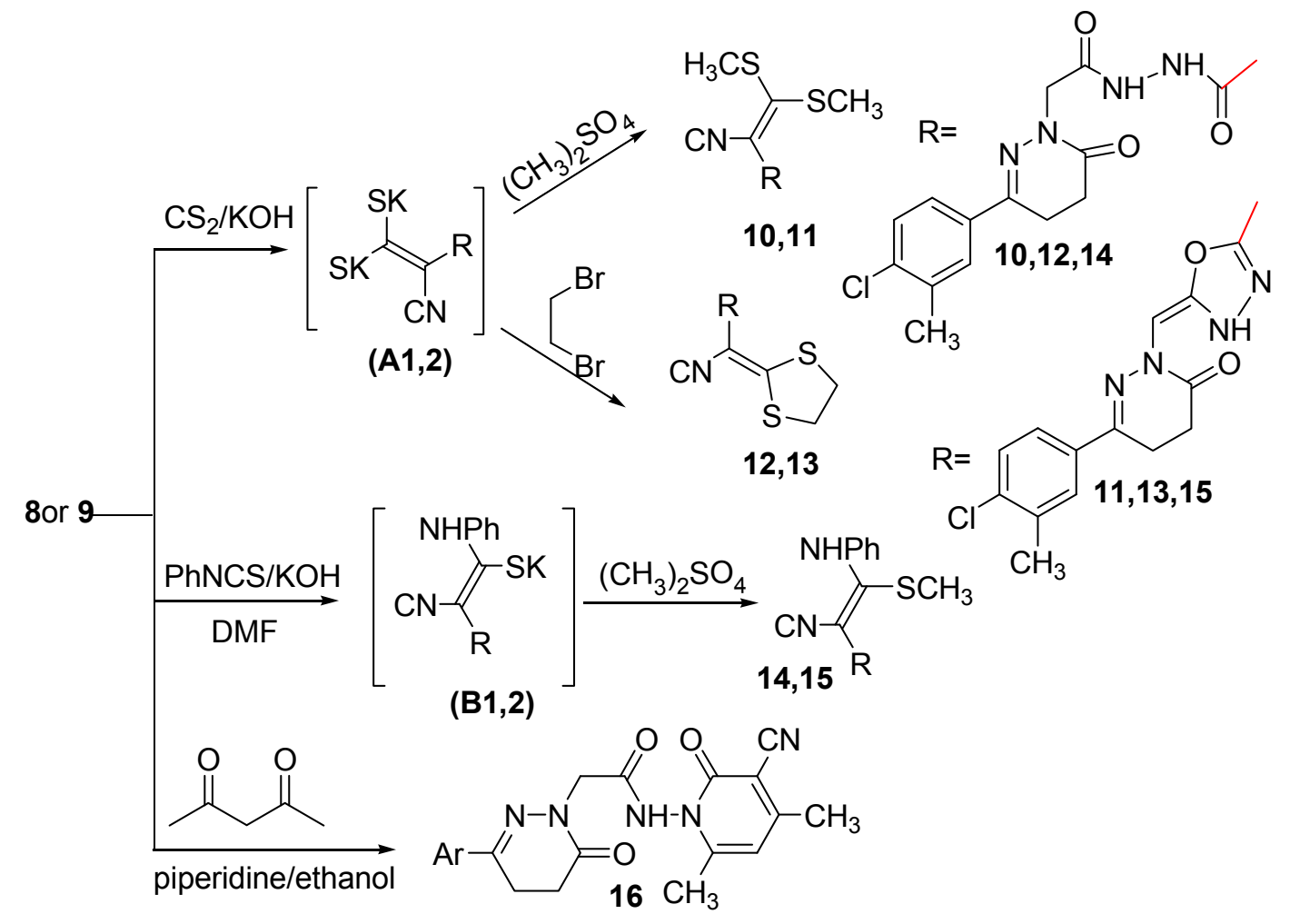

Scheme 3. Synthetic route for the preparation of compounds 10-16.

Also cyclobromination of the intermediates $(\mathrm{A} 1,2)$ with dibromoethane afforded compounds 12 and 13, respectively. The reaction proceeded via nucleophilic addition of the carbanions on $\mathrm{CS}_{2}$ to form the potassium salt intermediates $(\mathrm{A} 1,2)$ followed by in situ cyclization through a $\mathrm{S}_{\mathrm{N}} 2$ mechanism to yield the cyclic compounds 12 and 13, respectively. The structures of compounds 10-13 were established on the basis of analytical and spectral data. The IR spectra of compounds 10-13 showed bands characteristic for $\mathrm{NH}, \mathrm{CN}$ and $\mathrm{C}=\mathrm{O}$ groups in the range 3436-3200, 2214-2204 and $1677-1642 \mathrm{~cm}^{-1}$, respectively. Their ${ }^{1} \mathrm{H}-\mathrm{NMR}$ spectra are in accord with the suggested structures, where they are devoid of a signal corresponding to $\mathrm{CH}_{2} \mathrm{CN}$ protons. However, they displayed signals related to two $\mathrm{CH}_{3} \mathrm{~S}$ protons for compounds $\mathbf{1 0}$ and $\mathbf{1 1}$ at $\delta 2.89,2.88 \mathrm{ppm}$, respectively, and $\mathrm{SCH}_{2} \mathrm{CH}_{2} \mathrm{~S}$ protons for compounds $\mathbf{1 2}$ and $\mathbf{1 3}$ at $\delta 3.15$ and $4.41 \mathrm{ppm}$, respectively. The ${ }^{13} \mathrm{C}-\mathrm{NMR}$ spectra of compounds 12 and 13 exhibited signals at $\delta 34.28$ and $53.80 \mathrm{ppm}$, respectively indicating the presence of $\mathrm{S}-\mathrm{CH}_{2}-\mathrm{CH}_{2}-\mathrm{S}$. Further evidence was gained from mass spectra as they showed the correct molecular ion peaks for compounds 11-13 at $m / z$ 447, 463 and 445, respectively beside some other important peaks.

Furthermore, reaction of compounds $\mathbf{8}$ and $\mathbf{9}$ with phenyl isothiocyanate in the presence of $\mathrm{KOH}$ yielded the potassium salt intermediates) $(\mathrm{B} 1,2)$. Alkylation of the potassium salt intermediates 
$(\mathrm{B} 1,2)$ in situ with dimethyl sulfate gave compounds $\mathbf{1 4}$ and 15, respectively. The structures of compounds 14 and 15 were elucidated on the basis of the elemental analyses and spectral data. The IR spectra of compounds 14 and 15 displayed bands corresponding to $\mathrm{NH}, \mathrm{CN}$ and $\mathrm{C}=\mathrm{O}$ groups at 3182, 3333, 3211, 2203, 2202, 1673 and $1714 \mathrm{~cm}^{-1}$, respectively. Further support for the assigned structures of compounds 14 and 15 was gained from their ${ }^{1} \mathrm{H}-\mathrm{NMR}$ spectra. The ${ }^{1} \mathrm{H}-\mathrm{NMR}$ spectrum of compounds 14 showed characteristic signals for three $\mathrm{NH}$, aromatic protons, three $\mathrm{CH}_{2}$ and two $\mathrm{CH}_{3}$ at $10.59,10.27,10.07,6.92-8.71,4.41,3.00,2.75,2.58$ and $2.36 \mathrm{ppm}$, respectively, while, the ${ }^{1} \mathrm{H}-\mathrm{NMR}$ spectrum of compounds 15 showed characteristic signals for two $\mathrm{NH}$, aromatic protons, $=\mathrm{CH}$, two $\mathrm{CH}_{2}$ and two $\mathrm{CH}_{3}$ at 8.62, 7.57, 7.27-7.73, 6.96, 4.41, 3.00, 2.67, 2.41 and 2.34 ppm, respectively. The presence of an extra $\mathrm{NH}$ and $\mathrm{CH}_{3}$ protons and also the absence of the $\mathrm{CH}_{2} \mathrm{CN}$ protons supported the proposed structures of compounds 14 and 15. The ${ }^{13} \mathrm{C}-\mathrm{NMR}$ spectra were also in accordance with the proposed structures as they showed the presence of two $\mathrm{CH}_{3}$ and twelve aromatic carbons.

The cyanoacetyl acetohydrazide $\mathbf{8}$ was reacted with acetylacetone in piperidine to give $\mathbf{1 6}$. Compound 8 has two sites that have acidic hydrogens which can react with the carbonyl carbon of acetylacetone. The acetonitrile carbanion is more stabilized by the strong electron attracting character of both the $\mathrm{C}=\mathrm{O}$ and $\mathrm{C} \equiv \mathrm{N}$ groups. The structure of compound $\mathbf{1 6}$ was elucidated on the basis of the elemental analysis and spectral data. The IR spectrum showed three bands at 1677, 1657 and $1642 \mathrm{~cm}^{-1}$ assignable to three $\mathrm{C}=\mathrm{O}$ groups and also bands at 3180 and $2214 \mathrm{~cm}^{-1}$ assignable to NH and $\mathrm{C} \equiv \mathrm{N}$ groups, respectively, while the ${ }^{1} \mathrm{H}-\mathrm{NMR}$ spectrum of compound 16 showed signals at $\delta 2.28$ and 2.35 and $9.99 \mathrm{ppm}$ attributed to three $\mathrm{CH}_{3}$ and one $\mathrm{NH}$, respectively. The presence of one $\mathrm{NH}$ and three $\mathrm{CH}_{3}$ protons and also the absence of the $\mathrm{CH}_{2} \mathrm{CN}$ protons supported the proposed structure of compound 16. The ${ }^{13} \mathrm{C}-\mathrm{NMR}$ spectrum indicated the presence of three methyl groups.

Condensation of compounds 8 and 9 with salicylaldehyde in boiling ethanol and in the presence of ammonium acetate afforded the corresponding hydroxyphenyl derivatives 17 and 18, respectively (Scheme 4). The structures of compounds 17 and 18 were elucidated on the basis of their elemental analyses and spectral data. The IR spectra of compounds $\mathbf{1 7}$ and $\mathbf{1 8}$ showed bands for $\mathrm{OH}, \mathrm{NH}$ in the range 3188-3419 $\mathrm{cm}^{-1}$ and also showed signals attributed to $C \equiv \mathrm{N}$ groups in the range 2206-2207 $\mathrm{cm}^{-1}$, which indicated the formation of the open structures 17 and 18 and not the cyclic structures $17^{\prime}$ and 18 $^{\prime}$. The ${ }^{1} \mathrm{H}-\mathrm{NMR}$ spectrum of compound 17 showed signals corresponding to $\mathrm{OH}$, aromatic, $=\mathrm{CH}$ and two NH protons at 7.18, 7.38-7.75, 8.41 and $9.99 \mathrm{ppm}$, respectively, beside other signals corresponding to three $\mathrm{CH}_{2}$ and $\mathrm{CH}_{3}$ at 4.41, 3.01, 2.58 and 2.34 ppm, respectively. The ${ }^{1} \mathrm{H}-\mathrm{NMR}$ spectrum of compound 18 showed signals corresponding to $\mathrm{OH}$, aromatic, $=\mathrm{CH}$ and $\mathrm{NH}$ protons at 7.45-7.75 and $9.97 \mathrm{ppm}$, respectively, beside other signals corresponding to $2 \mathrm{CH}_{2}$ and $\mathrm{CH}_{3}$ at $2.99,2.72$ and 2.35 ppm, respectively. The ${ }^{13} \mathrm{C}$-NMR spectrum was also in accordance with the proposed structures of compounds 17 and 18. The presence of the $\mathrm{C} \equiv \mathrm{N}$ in the IR spectra and the $\mathrm{OH}$ proton in the ${ }^{1} \mathrm{H}-\mathrm{NMR}$ spectra indicated the formation of the open structures 17 and 18 not the cyclic structures $17^{\prime}$ and $18^{\prime}$. Further evidence was gained from mass spectra as they showed the correct molecular ion peaks for compounds 17 and 18 at $m / z 465$ and 447, respectively, beside some other important peaks.

The pyridazinylacetamide derivatives 19 and 20 were synthesized via multicomponent reaction of compounds 8 and 9 with $p$-anisaldehyde and the active methylene compound malononitrile. The structures of compounds 19 and 20 were deduced from studying their spectroscopic data. The IR spectrum of compound 19 revealed bands at 3457, 3271, $3178 \mathrm{~cm}^{-1}$ assignable to $\mathrm{NH}$ and $\mathrm{NH}_{2}$, in addition to three bands in the 1676-1623 range and a band at $2206 \mathrm{~cm}^{-1}$ assignable to $\mathrm{C}=\mathrm{O}$ and $\mathrm{C} \equiv \mathrm{N}$, respectively. The ${ }^{1} \mathrm{H}-\mathrm{NMR}$ spectrum of compound 19 showed signals attributable to $\mathrm{NH}_{2}$ and $\mathrm{NH}$ at $\delta 9.87$ and $10.00 \mathrm{ppm}$, respectively, and a signal at $\delta 3.87 \mathrm{ppm}$ assignable to $\mathrm{OCH}_{3}$ protons, plus signals for aliphatic and aromatic protons. The IR spectrum of compound 20 revealed bands for $\mathrm{NH}_{1} \mathrm{NH}_{2}$, $\mathrm{C} \equiv \mathrm{N}$ and $\mathrm{C}=\mathrm{O}$ at $3448,3178,2207$ and $1674 \mathrm{~cm}^{-1}$, respectively. The ${ }^{1} \mathrm{H}-\mathrm{NMR}$ spectrum of compound 20 showed signals attributable to $\mathrm{NH}$ and $\mathrm{NH}_{2}$ at $\delta 8.40$ and $2.72 \mathrm{ppm}$, respectively, and also signals at $\delta 6.95-7.71,5.07,4.41,3.74,3.02,2.60$ and $2.27 \mathrm{ppm}$ assignable to aromatic, $=\mathrm{CH}, \mathrm{CH}, \mathrm{OCH}_{3}$, two $\mathrm{CH}_{2}$ and $\mathrm{CH}_{3}$ protons, respectively. The presence of signals attributed to two $\mathrm{C} \equiv \mathrm{N}$ and $\mathrm{OCH}_{3}$ in 
the ${ }^{13} \mathrm{C}$-NMR spectra of compounds 19 and 20 supported the proposed structures. The presence of the $\mathrm{NH}_{2}$ in both the IR and ${ }^{1} \mathrm{H}-\mathrm{NMR}$ spectra and also the presence of $\mathrm{OCH}_{3}$ protons in the ${ }^{1} \mathrm{H}-\mathrm{NMR}$ spectra indicated the formation of compounds 19 and 20. Further evidence was gained from mass spectra, which showed the correct molecular ion peaks for compounds 19 and 20 at $m / z 543$ and 527, respectively, in addition to some other important peaks.

Because tetrazines are of considerable interest, not only because of their inherent biological potential [64], but also because of their value as building blocks in synthetic transformations, compound 8 was condensed with hydrazine hydrate to afford the tetrazine derivative 21 . The elemental analysis and the spectroscopic data confirmed its structure. The IR spectrum revealed the existence of one band for one $\mathrm{C}=\mathrm{O}$ at $1667 \mathrm{~cm}^{-1}$, beside bands corresponding to $\mathrm{NH}$, and $\mathrm{C} \equiv \mathrm{N}$ at 3312 and $2199 \mathrm{~cm}^{-1}$, respectively. The ${ }^{1} \mathrm{H}-\mathrm{NMR}$ spectrum of compound 21 showed signals corresponding to two protons of $\mathrm{NH}$ at 9.07 and $10.47 \mathrm{ppm}$, the higher value is due to hydrogen bonding, beside signals attributable to aromatic, six $\mathrm{CH}_{2}$ and $\mathrm{CH}_{3}$ protons at 7.35-7.71, 4.31, 4.26, 3.01, 2.55 and $2.36 \mathrm{ppm}$, respectively The ${ }^{13} \mathrm{C}-\mathrm{NMR}$ spectrum indicating the presence of $2 \mathrm{C}=\mathrm{N}$ carbons of the tetrazine ring as it showed a signal at $\delta 163.40 \mathrm{ppm}$. Further evidence was gained from mass spectrum as it showed the correct molecular ion peak at $m / z 357$ and some other major peaks.

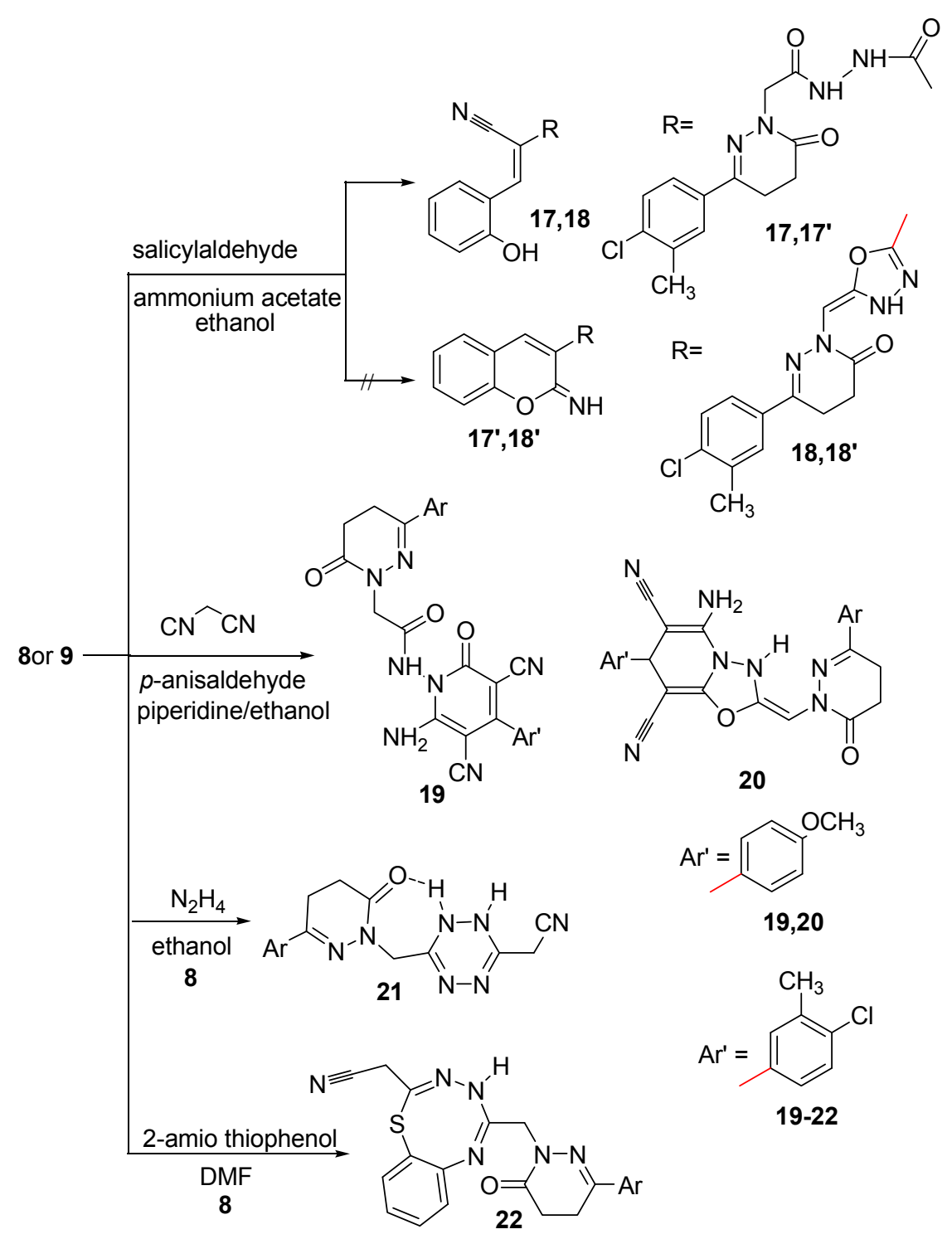

Scheme 4. Synthetic route for the preparation of compounds 17-22. 
The thiatriazocinyl derivative 22 was synthesized via the reaction of compound $\mathbf{8}$ with 2 -amino thiophenol. The IR spectrum showed bands at 3328, 3182 and $1660 \mathrm{~cm}^{-1}$ attributable to $\mathrm{NH}$ and $\mathrm{C}=\mathrm{O}$, and also it showed a band at $2205 \mathrm{~cm}^{-1}$ attributable to $\mathrm{C} \equiv \mathrm{N}$, which indicated that the nucleophilic attack did not occur at the $\mathrm{C} \equiv \mathrm{N}$ group. The ${ }^{1} \mathrm{H}-\mathrm{NMR}$ spectrum showed signals attributable to $\mathrm{NH}$, $\mathrm{CH}_{2} \mathrm{~N}$ and $\mathrm{CH}_{2} \mathrm{CN}$ protons at 5.44, 4.39 and $2.95 \mathrm{ppm}$, beside the other signals for aliphatic and aromatic protons and was devoid of a signal attributable to $\mathrm{NH}_{2}$. The $\mathrm{C}=\mathrm{O}$ group neighboring the $\mathrm{CH}_{2} \mathrm{CN}$ is more positive than the other $\mathrm{C}=\mathrm{O}$ group, consequently, the reaction occurred at this carbonyl group rather than the other one, followed by ring closure to afford the desired compound 22. Further evidence was gained from mass spectrum as it showed the correct molecular ion peak at $m / z 450$ beside some other important peaks.

\subsection{Pharmacological Activity}

\subsubsection{Antitumor Activity Using in Vitro Ehrlich Ascites Assay}

We assessed the cytotoxic action of the compounds (listed in Table 1 and shown in (Figure 3) against four human tumor cell lines namely: hepatocellular carcinoma (liver) HePG-2, colon cancer HCT-116, human prostate cancer cell line PC3 and mammary gland breast MCF-7.

Table 1. Cytotoxicity activity $\left(\mathrm{IC}_{50}\right)$ of the tested compounds on different cell lines.

\begin{tabular}{ccccc}
\hline \multirow{2}{*}{ Comp. No. } & \multicolumn{3}{c}{ In Vitro Cytotoxicity } & IC $_{\mathbf{5 0}}(\boldsymbol{\mu g} / \mathbf{m L})^{\mathbf{a}}$ \\
\cline { 2 - 5 } & HePG2 & HCT-116 & PC3 & MCF-7 \\
\hline $\mathbf{4}$ & $50.3 \pm 4.22$ & $64.7 \pm 4.11$ & $48.1 \pm 3.64$ & $58.4 \pm 3.67$ \\
$\mathbf{6}$ & $70.7 \pm 4.65$ & $72.6 \pm 4.51$ & $86.0 \pm 4.63$ & $80.4 \pm 4.75$ \\
$\mathbf{8}$ & $10.3 \pm 0.81$ & $8.1 \pm 0.35$ & $7.4 \pm 0.34$ & $5.6 \pm 0.30$ \\
$\mathbf{9}$ & $13.2 \pm 1.31$ & $14.8 \pm 1.53$ & $9.1 \pm 0.86$ & $10.5 \pm 1.04$ \\
$\mathbf{1 0}$ & $18.4 \pm 1.06$ & $20.0 \pm 1.96$ & $13.7 \pm 1.37$ & $12.3 \pm 1.08$ \\
$\mathbf{1 1}$ & $23.4 \pm 1.46$ & $30.3 \pm 2.64$ & $26.2 \pm 1.60$ & $28.7 \pm 1.83$ \\
$\mathbf{1 2}$ & $16.5 \pm 1.35$ & $16.9 \pm 1.14$ & $15.7 \pm 1.56$ & $19.7 \pm 1.76$ \\
$\mathbf{1 7}$ & $34.1 \pm 2.30$ & $37.5 \pm 2.67$ & $17.5 \pm 1.42$ & $23.1 \pm 1.51$ \\
$\mathbf{1 8}$ & $46.0 \pm 3.61$ & $40.7 \pm 2.63$ & $33.3 \pm 2.07$ & $29.4 \pm 2.00$ \\
$\mathbf{1 9}$ & $60.3 \pm 3.97$ & $68.3 \pm 3.88$ & $35.3 \pm 2.94$ & $41.5 \pm 2.43$ \\
$\mathbf{2 0}$ & $83.2 \pm 4.83$ & $>100$ & $70.9 \pm 4.75$ & $63.1 \pm 3.89$ \\
$\mathbf{2 1}$ & $11.8 \pm 1.12$ & $10.5 \pm 0.89$ & $8.9 \pm 0.45$ & $9.1 \pm 0.87$ \\
$\mathbf{5 - f u}$ & $7.9 \pm 0.28$ & $5.2 \pm 0.14$ & $8.3 \pm 0.25$ & $5.5 \pm 0.21$ \\
\hline
\end{tabular}

${ }^{\mathrm{a}} \mathrm{IC}_{50}(\mu \mathrm{g} / \mathrm{mL})$ : 1-10 (very strong), 11-20 (strong), 21-50 (moderate), 51-100 (weak), above 100 (non-cytotoxic).

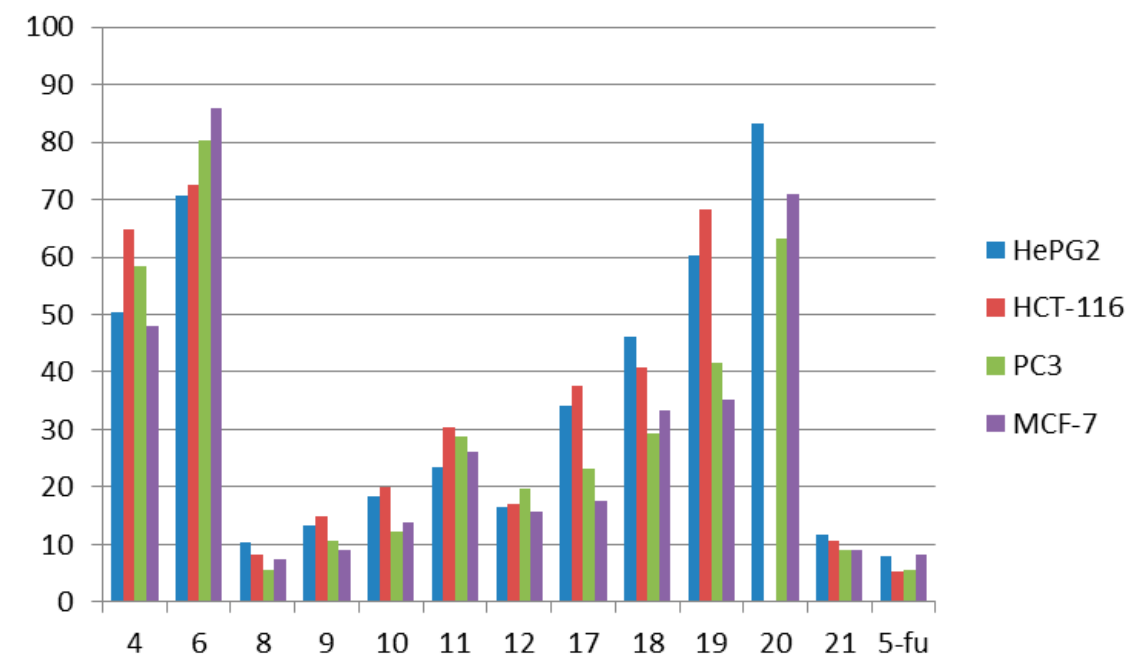

Figure 3. Cytotoxic activity of the tested compounds on different cell lines. 
In general, activity was observed by all of these molecules ranged from very strong to non-cytotoxic. The best results were observed for compound 8 (very strong activity) with $\mathrm{IC}_{50} 10.3 \pm 0.81,8.1 \pm 0.35,7.4 \pm 0.34$ and $5.6 \pm 0.30 \mu \mathrm{g} / \mathrm{mL}$ for HePG-2, HCT-116, PC-3 and for MCF-7 cell lines, respectively. Its activity towards MCF-7 cells is equal to that of 5-flurouracil (5-FU, $5.5 \pm 0.21 \mu \mathrm{g} / \mathrm{mL}$ ). Compound 21 showed very strong activity towards the HCT-116 cell line with $\mathrm{IC}_{50}(10.5 \pm 0.89 \mu \mathrm{g} / \mathrm{mL})$, the PC-3 cell line $(8.9 \pm 0.45)$, which is nearly equal to 5 -flurouracil (5-FU, $5.5 \pm 0.21 \mu \mathrm{g} / \mathrm{mL}$ ) and MCF-7 cell line $(9.1 \pm 0.87$ ), and it also showed strong activity towards the HePG-2 cell line (11.8 \pm 1.12$)$. Compound 9 showed very strong activity towards the PC-3 $(9.1 \pm 0.86)$ and MCF-7 cell lines $(10.5 \pm 1.04)$, and it also showed strong activity towards the HePG-2 and HCT-116 cell lines $13.2 \pm 1.31$ and $14.8 \pm 1.53 \mu \mathrm{g} / \mathrm{mL}$, respectively. Meanwhile, compounds $\mathbf{1 0}$ and $\mathbf{1 2}$ showed strong activity towards the four cell lines. Compound 10 showed $\mathrm{IC}_{50} 18.4 \pm 1.06,20.0 \pm 1.96$, $13.7 \pm 1.37$ and $12.3 \pm 1.08 \mu \mathrm{g} / \mathrm{mL}$ for the HePG-2, HCT-116, PC-3 and MCF-7 cell lines, respectively. Also, compound 12 showed $\mathrm{IC}_{50} 16.5 \pm 1.35,16.9 \pm 1.14,15.7 \pm 1.56$ and $19.7 \pm 1.76 \mu \mathrm{g} / \mathrm{mL}$ for the HePG-2, HCT-116, PC-3 and MCF-7 cell lines, respectively. The observed activities of compounds 6, 4, 11, 18, 19 and 20 ranged from moderate to non-cytotoxic, with $\mathrm{IC}_{50}$ values from $23.4 \pm 10$ to higher than 100. Finally, compound 17 showed strong activity towards the PC-3 cell line with $\mathrm{IC}_{50}$ $17.5 \pm 1.42$ and moderate activity towards the HePG-2, HCT-116 and MCF-7 cell lines with IC $_{50}$ values of $34.1 \pm 2.30,37.5 \pm 2.67$ and $23.1 \pm 1.51 \mu \mathrm{g} / \mathrm{mL}$, respectively. The relative viability of cells (\%) for the tested compounds is listed in Tables 2 and 3. The relationship between surviving fractions and the tested compounds concentration was plotted to obtain the survival curves of the four cell lines (the relative viability of cells (\%) curves for the tested compounds is shown in Supplementary Materials Figures S1-S13).

Table 2. Relative viability of cells (\%) for 5-FU and compounds 4, 6, 8, and 9-11.

\begin{tabular}{cccccc}
\hline Compounds & Conc. $(\mu \mathrm{g} / \mathrm{mL})$ & HePG-2 & HCT-116 & PC3 & MCF-7 \\
\hline \multirow{2}{*}{-FU } & $100 \mu \mathrm{g} / \mathrm{mL}$ & 8.6 & 7.2 & 8.1 & 7.7 \\
& $50 \mu \mathrm{g} / \mathrm{mL}$ & 17.1 & 12.0 & 15.8 & 14.3 \\
& $25 \mu \mathrm{g} / \mathrm{mL}$ & 24.0 & 19.3 & 22.5 & 21.5 \\
$12.5 \mu \mathrm{g} / \mathrm{mL}$ & 33.1 & 30.6 & 36.7 & 34.6 \\
& $6.25 \mu \mathrm{g} / \mathrm{mL}$ & 56.8 & 48.9 & 55.2 & 47.4 \\
& $3.125 \mu \mathrm{g} / \mathrm{mL}$ & 70.6 & 60.5 & 74.1 & 58.3 \\
& $1.56 \mu \mathrm{g} / \mathrm{mL}$ & 88.7 & 73.4 & 92.5 & 76.9 \\
& $100 \mu \mathrm{g} / \mathrm{mL}$ & 37.9 & 42.7 & 36.1 & 41.1 \\
$\mathbf{4}$ & $50 \mu \mathrm{g} / \mathrm{mL}$ & 48.8 & 55.5 & 48.4 & 52.9 \\
& $25 \mu \mathrm{g} / \mathrm{mL}$ & 63.0 & 67.2 & 62.5 & 64.6 \\
& $12.5 \mu \mathrm{g} / \mathrm{mL}$ & 75.6 & 81.3 & 74.2 & 78.2 \\
& $6.25 \mu \mathrm{g} / \mathrm{mL}$ & 93.1 & 94.9 & 95.6 & 99.3 \\
& $3.125 \mu \mathrm{g} / \mathrm{mL}$ & 100 & 100 & 100 & 100 \\
& $1.56 \mu \mathrm{g} / \mathrm{mL}$ & 100 & 100 & 100 & 100 \\
$\mathbf{6}$ & $100 \mu \mathrm{g} / \mathrm{mL}$ & 44.5 & 45.7 & 49.3 & 46.8 \\
& $50 \mu \mathrm{g} / \mathrm{mL}$ & 57.2 & 56.6 & 60.6 & 61.2 \\
& $25 \mu \mathrm{g} / \mathrm{mL}$ & 70.4 & 71.3 & 78.1 & 73.3 \\
& $12.5 \mu \mathrm{g} / \mathrm{mL}$ & 82.9 & 83.4 & 91.7 & 86.9 \\
& $6.25 \mu \mathrm{g} / \mathrm{mL}$ & 98.8 & 96.5 & 100 & 100 \\
& $3.125 \mu \mathrm{g} / \mathrm{mL}$ & 100 & 100 & 100 & 100 \\
& $1.56 \mu \mathrm{g} / \mathrm{mL}$ & 100 & 100 & 100 & 100 \\
& $100 \mu \mathrm{g} / \mathrm{mL}$ & 13.0 & 8.3 & 8.4 & 7.0 \\
& $50 \mu \mathrm{g} / \mathrm{mL}$ & 18.2 & 17.9 & 14.3 & 12.3 \\
& $25 \mu \mathrm{g} / \mathrm{mL}$ & 25.8 & 25.1 & 22.5 & 19.5 \\
& $12.5 \mu \mathrm{g} / \mathrm{mL}$ & 36.9 & 33.7 & 31.9 & 31.9 \\
& $6.25 \mu \mathrm{g} / \mathrm{mL}$ & 68.5 & 56.8 & 52.6 & 50.6 \\
& $3.125 \mu \mathrm{g} / \mathrm{mL}$ & 75.6 & 71.4 & 70.8 & 62.2 \\
& $1.56 \mu \mathrm{g} / \mathrm{mL}$ & 97.4 & 89.3 & 91.1 & 74.4 \\
\hline & & & & &
\end{tabular}


Table 2. Cont.

\begin{tabular}{cccccc}
\hline Compounds & Conc. $(\mu \mathrm{g} / \mathrm{mL})$ & HePG-2 & HCT-116 & PC3 & MCF-7 \\
\hline $\mathbf{9}$ & $100 \mu \mathrm{g} / \mathrm{mL}$ & 18.4 & 16.2 & 8.1 & 13.1 \\
& $50 \mu \mathrm{g} / \mathrm{mL}$ & 26.3 & 25.3 & 17.6 & 18.9 \\
& $25 \mu \mathrm{g} / \mathrm{mL}$ & 35.1 & 36.4 & 26.8 & 27.4 \\
$12.5 \mu \mathrm{g} / \mathrm{mL}$ & 43.7 & 48.1 & 37.2 & 38.2 \\
& $6.25 \mu \mathrm{g} / \mathrm{mL}$ & 61.0 & 67.5 & 55.5 & 66.7 \\
& $3.125 \mu \mathrm{g} / \mathrm{mL}$ & 84.2 & 88.7 & 78.1 & 76.1 \\
& $1.56 \mu \mathrm{g} / \mathrm{mL}$ & 100 & 100 & 96.0 & 98.5 \\
& $100 \mu \mathrm{g} / \mathrm{mL}$ & 23.1 & 20.1 & 19.0 & 15.1 \\
$\mathbf{1 0}$ & $50 \mu \mathrm{g} / \mathrm{mL}$ & 30.0 & 32.4 & 26.4 & 24.2 \\
& $25 \mu \mathrm{g} / \mathrm{mL}$ & 41.5 & 42.8 & 35.9 & 35.1 \\
& $12.5 \mu \mathrm{g} / \mathrm{mL}$ & 53.8 & 55.5 & 43.2 & 42.8 \\
& $6.25 \mu \mathrm{g} / \mathrm{mL}$ & 67.3 & 71.2 & 65.3 & 59.9 \\
& $3.125 \mu \mathrm{g} / \mathrm{mL}$ & 89.7 & 95.3 & 83.6 & 81.7 \\
& $1.56 \mu \mathrm{g} / \mathrm{mL}$ & 100 & 100 & 100 & 100 \\
& $100 \mu \mathrm{g} / \mathrm{mL}$ & 24.8 & 29.1 & 26.6 & 25.9 \\
$\mathbf{1 1}$ & $50 \mu \mathrm{g} / \mathrm{mL}$ & 35.7 & 39.7 & 37.3 & 38.8 \\
& $25 \mu \mathrm{g} / \mathrm{mL}$ & 47.4 & 52.5 & 49.2 & 50.1 \\
& $12.5 \mu \mathrm{g} / \mathrm{mL}$ & 58.1 & 63.8 & 60.5 & 65.9 \\
& $6.25 \mu \mathrm{g} / \mathrm{mL}$ & 72.3 & 77.9 & 74.1 & 78.6 \\
& $3.125 \mu \mathrm{g} / \mathrm{mL}$ & 91.8 & 96.2 & 97.2 & 96.7 \\
& $1.56 \mu \mathrm{g} / \mathrm{mL}$ & 100 & 100 & 100 & 100 \\
\hline
\end{tabular}

Table 3. Relative viability of cells (\%) for compounds 12, and 17-21.

\begin{tabular}{cccccc}
\hline Compounds & Conc. $(\mu \mathrm{g} / \mathrm{mL})$ & HePG-2 & HCT-116 & PC3 & MCF-7 \\
\hline 12 & $100 \mu \mathrm{g} / \mathrm{mL}$ & 19.9 & 18.3 & 21.0 & 22.9 \\
& $50 \mu \mathrm{g} / \mathrm{mL}$ & 27.2 & 26.8 & 29.2 & 31.2 \\
$25 \mu \mathrm{g} / \mathrm{mL}$ & 36.1 & 39.5 & 38.3 & 43.8 \\
$12.5 \mu \mathrm{g} / \mathrm{mL}$ & 51.3 & 50.4 & 47.5 & 54.2 \\
& $6.25 \mu \mathrm{g} / \mathrm{mL}$ & 71.4 & 72.6 & 65.4 & 71.3 \\
& $3.125 \mu \mathrm{g} / \mathrm{mL}$ & 89.5 & 90.7 & 86.7 & 88.5 \\
$1.56 \mu \mathrm{g} / \mathrm{mL}$ & 100 & 100 & 100 & 100 \\
$100 \mu \mathrm{g} / \mathrm{mL}$ & 29.1 & 31.5 & 19.7 & 24.2 \\
$\mathbf{1 7}$ & $50 \mu \mathrm{g} / \mathrm{mL}$ & 42.2 & 45.2 & 27.5 & 35.5 \\
& $25 \mu \mathrm{g} / \mathrm{mL}$ & 51.9 & 55.8 & 39.1 & 46.1 \\
& $12.5 \mu \mathrm{g} / \mathrm{mL}$ & 71.3 & 69.7 & 51.6 & 57.3 \\
& $6.25 \mu \mathrm{g} / \mathrm{mL}$ & 84.5 & 81.3 & 73.4 & 72.6 \\
& $3.125 \mu \mathrm{g} / \mathrm{mL}$ & 100 & 99.4 & 92.4 & 96.8 \\
$1.56 \mu \mathrm{g} / \mathrm{mL}$ & 100 & 100 & 100 & 100 \\
$100 \mu \mathrm{g} / \mathrm{mL}$ & 35.9 & 33.6 & 31.1 & 28.6 \\
$\mathbf{1 8}$ & $50 \mu \mathrm{g} / \mathrm{mL}$ & 48.1 & 45.5 & 42.5 & 39.5 \\
& $25 \mu \mathrm{g} / \mathrm{mL}$ & 60.5 & 57.1 & 53.2 & 51.3 \\
& $12.5 \mu \mathrm{g} / \mathrm{mL}$ & 72.8 & 70.0 & 65.4 & 62.9 \\
& $6.25 \mu \mathrm{g} / \mathrm{mL}$ & 89.2 & 91.2 & 78.0 & 77.8 \\
& $3.125 \mu \mathrm{g} / \mathrm{mL}$ & 100 & 100 & 99.3 & 96.4 \\
& $1.56 \mu \mathrm{g} / \mathrm{mL}$ & 100 & 100 & 100 & 100 \\
& $100 \mu \mathrm{g} / \mathrm{mL}$ & 38.7 & 43.7 & 29.5 & 31.9 \\
& $50 \mu \mathrm{g} / \mathrm{mL}$ & 53.2 & 56.5 & 42.8 & 46.0 \\
$25 \mu \mathrm{g} / \mathrm{mL}$ & 70.3 & 69.1 & 53.1 & 59.2 \\
& $12.5 \mu \mathrm{g} / \mathrm{mL}$ & 89.1 & 84.2 & 72.2 & 71.3 \\
$\mathbf{1 9}$ & $6.25 \mu \mathrm{g} / \mathrm{mL}$ & 100 & 98.3 & 84.6 & 93.5 \\
& $3.125 \mu \mathrm{g} / \mathrm{mL}$ & 100 & 100 & 100 & 100 \\
& $1.56 \mu \mathrm{g} / \mathrm{mL}$ & 100 & 100 & 100 & 100 \\
\hline & & & & &
\end{tabular}


Table 3. Cont.

\begin{tabular}{cccccc}
\hline Compounds & Conc. $(\mu \mathrm{g} / \mathrm{mL})$ & HePG-2 & HCT-116 & PC3 & MCF-7 \\
\hline $\mathbf{2 0}$ & $100 \mu \mathrm{g} / \mathrm{mL}$ & 48.1 & 53.7 & 45.0 & 39.8 \\
& $50 \mu \mathrm{g} / \mathrm{mL}$ & 61.3 & 72.5 & 56.2 & 54.6 \\
$25 \mu \mathrm{g} / \mathrm{mL}$ & 73.4 & 85.4 & 71.6 & 70.3 \\
& $12.5 \mu \mathrm{g} / \mathrm{mL}$ & 86.7 & 98.9 & 82.1 & 94.1 \\
& $6.25 \mu \mathrm{g} / \mathrm{mL}$ & 99.8 & 100 & 98.4 & 100 \\
& $3.125 \mu \mathrm{g} / \mathrm{mL}$ & 100 & 100 & 100 & 100 \\
& $1.56 \mu \mathrm{g} / \mathrm{mL}$ & 100 & 100 & 100 & 100 \\
$\mathbf{2 1}$ & $100 \mu \mathrm{g} / \mathrm{mL}$ & 15.7 & 13.1 & 7.7 & 8.4 \\
& $50 \mu \mathrm{g} / \mathrm{mL}$ & 22.1 & 19.2 & 16.1 & 17.3 \\
& $25 \mu \mathrm{g} / \mathrm{mL}$ & 27.4 & 27.6 & 24.5 & 26.5 \\
& $12.5 \mu \mathrm{g} / \mathrm{mL}$ & 42.9 & 38.5 & 38.2 & 37.0 \\
& $6.25 \mu \mathrm{g} / \mathrm{mL}$ & 65.8 & 66.8 & 55.3 & 55.4 \\
& $3.125 \mu \mathrm{g} / \mathrm{mL}$ & 83.2 & 75.7 & 78.1 & 78.8 \\
& $1.56 \mu \mathrm{g} / \mathrm{mL}$ & 99.0 & 97.1 & 94.4 & 95.9 \\
\hline
\end{tabular}

2'-C-Cyano-2'-deoxy-1- $\beta$-D-arabinopentofuranosylcytosine (CNDAC) [65] is a nucleoside analogue with a novel mechanism of action that is being evaluated in clinical trials. Incorporation of CNDAC triphosphate into DNA and extension during replication leads to single-strand breaks directly caused by $\beta$-elimination. These breaks, or the lesions that arise from further processing, cause cells to arrest in G2. The electron withdrawing effect [66] of the cyano group at the arabinose $2^{\prime}$ - $\beta$-position increases the acidity of the $2^{\prime}-\alpha$ proton and facilitates a $\beta$-elimination reaction involving an oxygen of the phosphate group at the $3^{\prime}-\beta$ position that leads to single strand break that affords a DNA molecule lacking a $3^{\prime}$-hydroxyl, which prevents its repair by ligation and leads to inhibition of the cell cycle at the $G_{2}$ phase (Scheme 5).

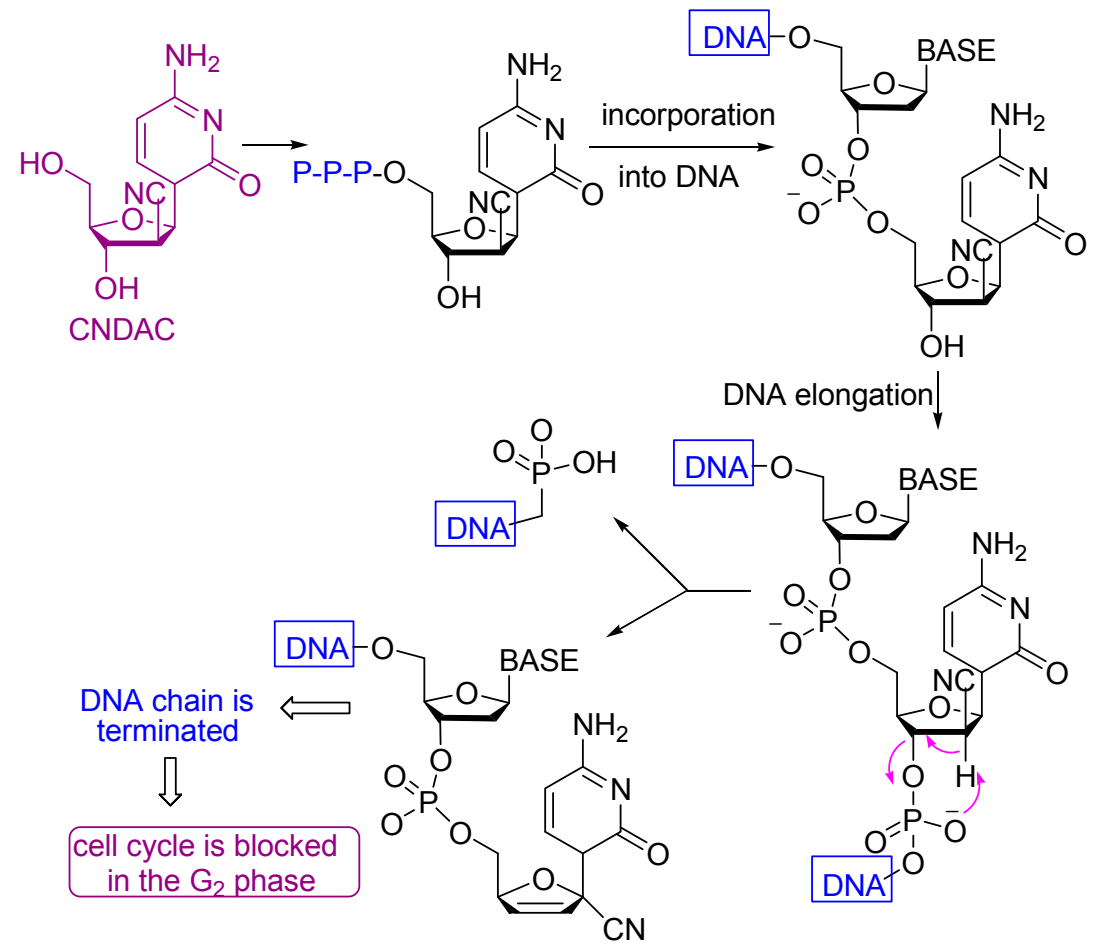

Scheme 5. Mechanism of the antitumor action of CNDAC. 


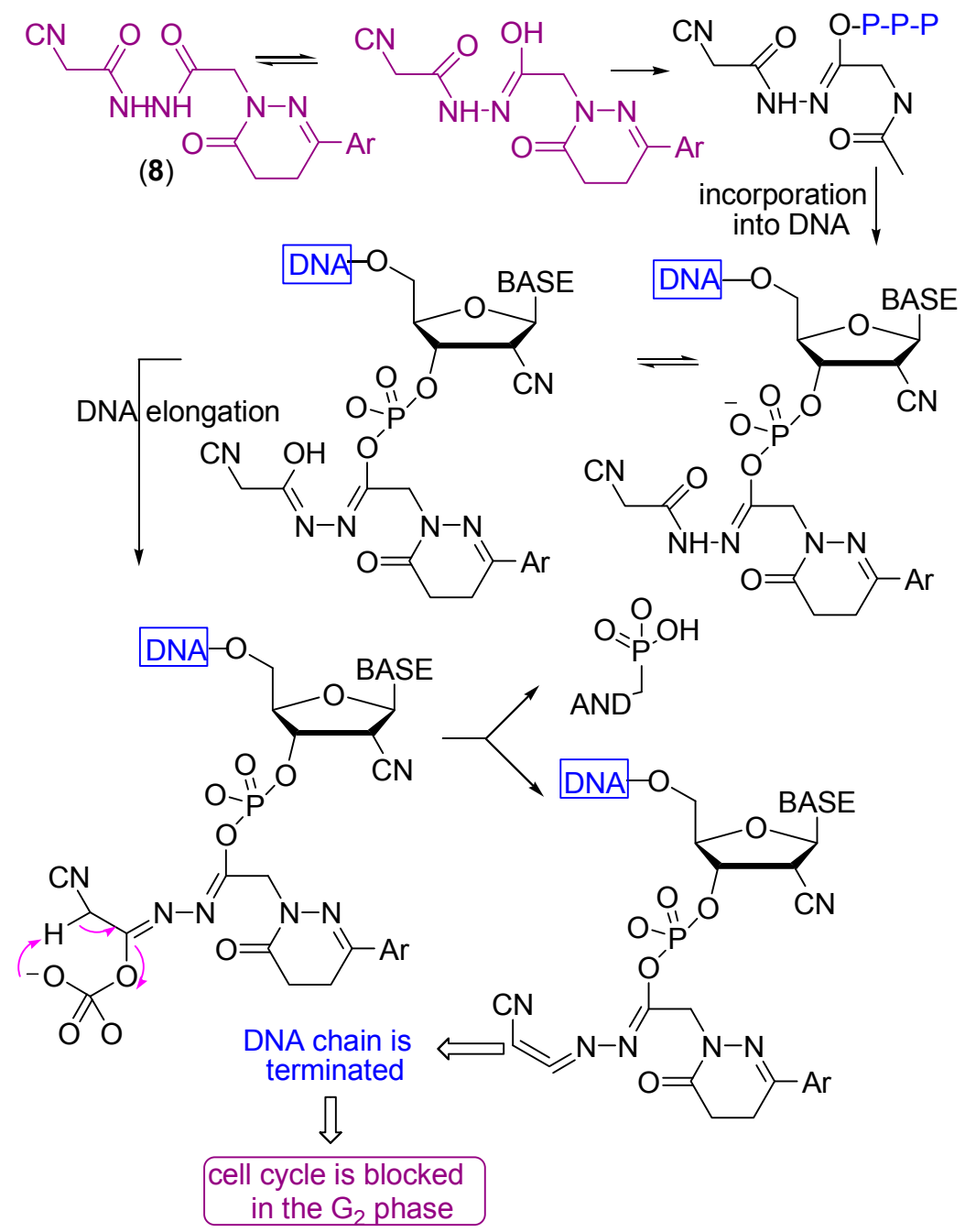

Scheme 6. Mechanism of the antitumor action of compound 8.

All the tested compounds showed activity, which may be due to the presence of either $\mathrm{NH}_{2}$, $\mathrm{NH}$ or $\mathrm{OH}$ groups which can add to any unsaturated moiety in the DNA or form a hydrogen bond with either of the nucleobases of the DNA which causes their damage to different extents. Also the presence of $\mathrm{C} \equiv \mathrm{N}$ with $\alpha-\mathrm{H}$ and $\beta-\mathrm{OH}$ enhances the cytotoxicity of compound 8 (Scheme 6). The electron withdrawing effect of the cyano group increases the acidity of the $\alpha$-proton and facilitates a $\beta$-elimination reaction involving the formation of the azaallene $(-\mathrm{C}=\mathrm{C}=\mathrm{N}-)$ group. The lower activities of the other compounds compared to compound 8 is due to the absence of either $\alpha-\mathrm{H}, \beta-\mathrm{OH}$ or the $\mathrm{C} \equiv \mathrm{N}$ group.

2.2.2. Antioxidant Activity Using 2,2'-Azino-bis(3-ethylbenzthiazoline-6-sulfonic Acid (ABTS) Inhibition

Twelve compounds were tested for antioxidant activity as reflected in the ability to inhibit oxidation in rat brain and kidney homogenates (Table 4). Compounds $\mathbf{8}$ and $\mathbf{2 1}$ showed very high \% inhibition, nearly equal to ascorbic acid (88.1\%, 86.0\% and $88.9 \%$, respectively). Compounds 10 and $\mathbf{1 2}$ showed high inhibition $\%$ of 71.7 and 74.9 , respectively. In addition the rest of the compounds 4, 6, 11, $12,17,18,19$ and 20 exhibited moderate to weak antioxidant activity ranging from $68.0 \%-47.0 \%$. 
Table 4. Antioxidant activity and bleomycin-dependent DNA damage caused by the tested compounds ${ }^{a}$.

\begin{tabular}{cccc}
\hline Comp. No. & $\begin{array}{c}\text { Antioxidant Activity } \\
\text { Absorbance }\end{array}$ & $\begin{array}{c}\text { (ABTS Method) } \\
\text { Inhibition (\%) }\end{array}$ & $\begin{array}{c}\text { Bleomycin Dependent } \\
\text { DNA Damage }\end{array}$ \\
\hline $\mathbf{4}$ & 0.261 & 48.4 & 0.116 \\
$\mathbf{6}$ & 0.271 & 46.4 & 0.129 \\
$\mathbf{8}$ & 0.060 & 88.1 & 0.069 \\
$\mathbf{9}$ & 0.127 & 74.9 & 0.077 \\
$\mathbf{1 0}$ & 0.143 & 71.7 & 0.088 \\
$\mathbf{1 1}$ & 0.204 & 59.7 & 0.094 \\
$\mathbf{1 2}$ & 0.162 & 68.0 & 0.081 \\
$\mathbf{1 7}$ & 0.201 & 60.3 & 0.104 \\
$\mathbf{1 8}$ & 0.230 & 54.5 & 0.074 \\
$\mathbf{1 9}$ & 0.257 & 49.2 & 0.122 \\
$\mathbf{2 0}$ & 0.268 & 47.0 & 0.143 \\
$\mathbf{2 1}$ & 0.071 & 86.0 & 0.074 \\
Control of ABTS & 0.506 & 0 & - \\
Ascorbic acid & 0.056 & 88.9 & 0.072 \\
\hline
\end{tabular}

a All experiments were performed three times. The data are expressed as the mean-standard error of the mean (S.E.M.).

\subsubsection{Bleomycin-Dependent Deoxyribonucleic Acid (DNA) Damage}

Bleomycin is a glycopeptide antibiotic routinely used as an antitumor agent. The bleomycin assay has been adopted for assessing the pro-oxidant effect of food antioxidants. The antitumor antibiotic bleomycin binds iron ions and DNA. The bleomycin-iron complex degrades DNA when heated with thiobarbituric acid (TBA) to yield a pink chromogenic. Upon the addition of suitable reducing agents antioxidant competes with DNA and diminishes chromogenic formation [67].

To show the mechanism of action of the tested compounds $4,6,8,9,10,11,12,17,18,19,20$ and 21, their protective activity against DNA damage induced by the bleomycin-iron complex were examined. The results (Table 4) showed that compounds 8, 9, 10, 11, 12 and 21 have the ability to protect DNA from the induced damage by bleomycin. Compound 8 showed very high protection (0.069) against DNA damage induced by the bleomycin-iron complex which is higher than ascorbic acid as a standard (0.072). Compounds 9 and 21 meanwhile showed very high protection $(0.077,0.074)$, respectively, against DNA damage induced by the bleomycin-iron complex which is approximately equal to ascorbic acid used as a standard (0.072). Compounds 10,11 and 12 showed moderate ability $(0.088,0.094$ and 0.081 respectively). The rest of the compounds $4,6,17,18,19$ and 20 on the other hand exhibited low activities. Thus, all the tested compounds diminish the chromogenic formation between the damage DNA and TBA.

\subsubsection{Structure Activity Relationship}

By comparing the experimental cytotoxicity of the compounds reported in this study to their structures, the following structure activity relationships (SAR) were postulated.

- Compound 8 showed very strong activities against the four cell lines, which may be due to the presence of two $\mathrm{NH}$ and $\mathrm{C} \equiv \mathrm{N}$ groups.

- Compound 9 showed very strong activities against the PC-3 and MCF-7 cell lines, and strong activity against the HePG2 and HCT-116 cell lines which may be due to the presence of NH and the oxadiazole moiety.

- Compounds $\mathbf{1 0}$ and $\mathbf{1 2}$ showed strong activity against the four cell lines, which may be due to the presence of two NH groups and the sulfur atom, which has a vacant orbital that can accept electrons.

- Compound 17 showed strong and moderate activity due to the presence of $\mathrm{NH}$ and $\mathrm{OH}$ groups. 
- Compound 21 showed very strong activities against the HCT-116, PC-3 and MCF-7 cell lines, and strong activity against the HePG2 cell line which may be due to the presence of $\mathrm{NH}$ of the tetrazine moiety and $\mathrm{C} \equiv \mathrm{N}$ group with $\alpha-\mathrm{H}$ and $\beta-\mathrm{NH}$.

- Compounds 4, 6, 11, 18, 19 and 20 showed either weak or moderate activities because of the absence of $\mathrm{C} \equiv \mathrm{N}$ as in compounds 4,6 or the absence of $\alpha-\mathrm{H}$ as in compounds 11, 18, 19 and 20.

\section{Materials and Methods}

\subsection{General Information}

All melting points were measured on a Gallenkamp melting point apparatus and were uncorrected. The infrared spectra were recorded using potassium bromide disks on a Mattson FTIR spectrophotometer (Mattson, New York, NY, USA). ${ }^{1} \mathrm{H}-\mathrm{NMR}$ spectra were run at $300 \mathrm{MHz}$, on a Varian Mercury VX-300 NMR spectrometer (Bruker, Rheinstetten, Germany) using TMS as an internal standard in deuterated dimethylsulphoxide. ${ }^{13} \mathrm{C}-\mathrm{NMR}$ spectra were recorded on a Bruker spectrometer at $100 \mathrm{MHz}$. Chemical shifts $\delta$ are quoted in ppm. The mass spectra were recorded on a GCMS-QP-1000EX mass spectrometer (Shimadzu, Kyoto, Japan) at 70 e.V. All the spectral measurements were carried out at the Microanalytical Center of Cairo University, Cairo, Egypt; and the Main Defense Chemical Laboratory, Cairo, Egypt and Zagazig University, Zagazig, Egypt. The elemental analyses were carried out at the Microanalytical Center of Ain Shams University, Cairo, Egypt. The pharmaceutical activity assays were carried out at the Pharmacology Department, Faculty of Pharmacy, EL-Mansoura University, EL-Mansoura, Egypt. All reagents used in this study were commercially available. Ethyl 2-(3-(4-chloro-3-methylphenyl)-6-oxo-5,6-dihydropyridazin-1(4H)-yl) acetate (1) and 2-(3-(4-chloro-3-methylphenyl)-6-oxo-5,6-dihydropyridazin-1(4H)-yl)aceto-hydrazide (3) were prepared by previously reported procedures [25].

\subsection{Synthesis}

\subsubsection{Ethyl 2-(8-(4-Chloro-3-methylphenyl)-3-thioxo-1,2,4,6,7-pentaazaspiro[4,5]deca-1,7-diene-6-yl)acetate (2)}

A solution of compound $1(0.01 \mathrm{~mol}, 3.08 \mathrm{~g})$ and thiosemicarbazide $(0.01 \mathrm{~mol}, 0.91 \mathrm{~g})$ in ethanol $(30 \mathrm{~mL})$ was refluxed for $6 \mathrm{~h}$. The separated solid was filtered off, dried and recrystallized from ethanol as pale yellow crystals, yield 50\%, mp 187-188; IR ( $\left.\mathrm{KBr} \mathrm{cm}^{-1}\right)$ : 3371, $3263(\mathrm{NH}), 1741$ (C=O); ${ }^{1} \mathrm{H}-\mathrm{NMR}$ (DMSO- $d_{6}$ ): $\delta 8.58$ (br.s, $1 \mathrm{H}, \mathrm{NH} \mathrm{D}_{2} \mathrm{O}$ exchangeable), 7.40-7.77 (m, 3H, Ar-H), $4.63\left(\mathrm{~s}, 2 \mathrm{H}, \mathrm{NCH}_{2}\right)$, $4.14\left(\mathrm{q}, 2 \mathrm{H}, J=6.9 \mathrm{~Hz}, \mathrm{OCH}_{2}\right), 2.98,2.56\left(2 \mathrm{t}, 4 \mathrm{H}, J=8.1,8.4 \mathrm{~Hz}, 2 \mathrm{CH}_{2}\right), 2.37\left(\mathrm{~s}, 3 \mathrm{H}, \mathrm{CH}_{3}\right), 1.20(\mathrm{t}, 3 \mathrm{H}$, $\left.J=6.9 \mathrm{~Hz}, \mathrm{CH}_{3}\right) ;{ }^{13} \mathrm{C}-\mathrm{NMR}$ (DMSO- $d_{6}$ ): $14.03,19.60,22.34,26.00,50.22,60.76,94.28,128.57,128.99$, 131.32, 133.61, 135.62, 137.04, 149.60, 168.44, 181.18; MS m/z $379\left(\mathrm{M}^{+}, 0.46\right), 308$ (100), 237 (30.66), 55 (12.50). Found: $\mathrm{C}, 60.01 ; \mathrm{H}, 4.80 ; \mathrm{Cl}, 9.27 ; \mathrm{N}, 18.65 ; \mathrm{S}, 8.46 \%$. Calcd for $\mathrm{C}_{16} \mathrm{H}_{18} \mathrm{ClN}_{5} \mathrm{O}_{2} \mathrm{~S}: \mathrm{C}, 50.59 ; \mathrm{H}$, $4.78 ; \mathrm{Cl}, 9.33 ; \mathrm{N}, 18.44 ; \mathrm{S}, 8.44 \%$.

\subsubsection{2-(3-(4-Chloro-3-methylphenyl)-6-oxo-5,6-dihydropyridazin-1(4H)-yl)-N'-(2-oxoindolin-3-ylidene) -acetohydrazide (4)}

The acetohydrazide $3(0.001 \mathrm{~mol}, 2.94 \mathrm{~g})$ was condensed with isatin $(0.001 \mathrm{~mol}, 1.47 \mathrm{~g})$ in ethyl alcohol $(25 \mathrm{~mL})$ and a few drops of acetic acid on a water bath for $3 \mathrm{~h}$. The solvent was evaporated and the reaction mixture was poured onto crushed ice. The separated solid was filtered off, dried and recrystallized from toluene as brown crystals in $2.19 \mathrm{~g} \mathrm{(52 \% );} \mathrm{mp}>168-170{ }^{\circ} \mathrm{C}$; $\mathrm{IR}\left(\mathrm{KBr} \mathrm{cm}^{-1}\right): 3173$ (NH), 1695, $1642(\mathrm{C}=\mathrm{O}), 1619(\mathrm{C}=\mathrm{N}) ;{ }^{1} \mathrm{H}-\mathrm{NMR}$ (DMSO- $\left.d_{6}\right): \delta 13.21$ (br.s, $1 \mathrm{H}, \mathrm{NH} \mathrm{D}_{2} \mathrm{O}$ exchangeable), 12.57 (br.s, $1 \mathrm{H}, \mathrm{OH} \mathrm{D}_{2} \mathrm{O}$ exchangeable), 11.21 (br.s, $1 \mathrm{H}, \mathrm{NH} \mathrm{D}_{2} \mathrm{O}$ exchangeable), 6.88-7.79 (m, 7H, $\mathrm{Ar}-\mathrm{H}), 4.67\left(\mathrm{~s}, 2 \mathrm{H}, \mathrm{NCH}_{2}\right), 3.07,2.62\left(2 \mathrm{t}, 4 \mathrm{H}, \mathrm{J}=8.1 \mathrm{~Hz}, 2 \mathrm{CH}_{2}\right), 2.36\left(\mathrm{~s}, 3 \mathrm{H}, \mathrm{CH}_{3}\right) ;{ }^{13} \mathrm{C}-\mathrm{NMR}\left(\mathrm{DMSO}-d_{6}\right)$ : 19.41, 22.31, 26.08, 51.85, 122.50, 124.52, 128.14, 128.43, 128.87, 131.17, 131.61, 133.62, 134.01, 134.74, 135.55, 142.48, 149.70, 151.53, 162.41, 165.91, 169.35; MS m/z (\%): $423\left(\mathrm{M}^{+}, 28.14\right), 279$ (63.03), 235 
(72.03), 91 (100). Anal. Calcd for $\mathrm{C}_{21} \mathrm{H}_{18} \mathrm{ClN}_{5} \mathrm{O}_{3}$ : C, 59.51; $\mathrm{H}, 4.28 ; \mathrm{Cl}, 8.36 ; \mathrm{N}, 16.52$. Found: $\mathrm{C}, 59.60$; $\mathrm{H}, 4.16 ; \mathrm{Cl}, 8.40 ; \mathrm{N}, 16.54$.

3.2.3. 6-(4-Chloro-3-methylphenyl)-2-(2-(3,5-dimethyl-1H-pyrazol-1-yl)-2-oxoethyl)-4,5-dihydropyridazin $-3(2 \mathrm{H})$-one (5)

A mixture of acetohydrazide $3(0.01 \mathrm{~mol}, 2.94 \mathrm{~g})$, acetylacetone $(0.012 \mathrm{~mol}, 1.1 \mathrm{~mL})$ and piperidine (few drops) was refluxed in ethanol $(20 \mathrm{~mL})$ for $6 \mathrm{~h}$. The precipitated solid obtained was collected by filtration, dried and recrystallized from ethanol as white crystals in $2.57 \mathrm{~g}(72 \%), \mathrm{mp} 129-130{ }^{\circ} \mathrm{C}$; IR $\left(\mathrm{KBr} \mathrm{cm}^{-1}\right): 1731,1681(\mathrm{C}=\mathrm{O}) ;{ }^{1} \mathrm{H}-\mathrm{NMR}$ (DMSO- $\left.d_{6}\right): \delta 7.40-7.78(\mathrm{~m}, 3 \mathrm{H}, \mathrm{Ar}-\mathrm{H}), 6.25$ (s, $1 \mathrm{H}$, pyrazolo), $5.22\left(\mathrm{~s}, 2 \mathrm{H}, \mathrm{NCH}_{2}\right), 3.05,2.61\left(2 \mathrm{t}, 4 \mathrm{H}, J=8.1,8.4 \mathrm{~Hz}, 2 \mathrm{CH}_{2}\right), 2.49\left(\mathrm{~s}, 3 \mathrm{H}, \mathrm{CH}_{3}\right), 2.45\left(\mathrm{~s}, 3 \mathrm{H}, \mathrm{CH}_{3}\right), 2.21(\mathrm{~s}$, $\left.3 \mathrm{H}, \mathrm{CH}_{3}\right) ;{ }^{13} \mathrm{C}-\mathrm{NMR}$ (DMSO- $d_{6}$ ): 13.45, 13.63, 19.54, 22.33, 26.03, 51.81, 111.44, 128.54, 128.90, 131.23, 133.60, 135.57, 136.97, 143.66, 149.54, 149.98, 166.07, 167.51; MS m/z $358\left(\mathrm{M}^{+}, 27.99\right), 262$ (100), 179 (13.49), 97 (39.80). Found: C, 60.10; H, 5.28; Cl, 9.79; N, 15.57\%. Calcd for $\mathrm{C}_{18} \mathrm{H}_{19} \mathrm{ClN}_{4} \mathrm{O}_{2}: \mathrm{C}, 60.25 ; \mathrm{H}$, $5.34 ; \mathrm{Cl}, 9.88 ; \mathrm{N}, 15.61 \%$.

\subsubsection{General Procedure for the Synthesis of Compounds $\mathbf{6}$ and $\mathbf{7}$}

A solution of the acetohydrazide $3(0.01 \mathrm{~mol}, 2.94 \mathrm{~g})$ and ethyl acetoacetate or ethyl benzoylacetate $(0.01 \mathrm{~mol})$ in ethanol $(30 \mathrm{~mL})$ was refluxed for $6 \mathrm{~h}$. The separated solids were filtered off, dried and recrystallized from the proper solvent to give 6 and 7.

6-(4-Chloro-3-methylphenyl)-2-(2-(3-methyl-5-oxo-2H-pyrazol-1(5H)-yl)-2-oxoethyl)-4,5-dihydropyridazin -3(2H)-one (6). This compound was obtained as white crystals (benzene) in $2.44 \mathrm{~g}(68 \%), \mathrm{mp} 270-272{ }^{\circ} \mathrm{C}$; IR $\left(\mathrm{KBr} \mathrm{cm}^{-1}\right)$ : $3195(\mathrm{NH}), 1675,1661,1642(\mathrm{C}=\mathrm{O}) ;{ }^{1} \mathrm{H}-\mathrm{NMR}\left(\mathrm{DMSO}-d_{6}\right): \delta 9.98\left(\mathrm{~s}, 1 \mathrm{H}, \mathrm{OH} \mathrm{D} \mathrm{O}_{2}\right.$ exchangeable), 7.43-7.75 (m, 4H, 3Ar-H,1H pyrazolo), $4.41\left(\mathrm{~s}, 2 \mathrm{H}, \mathrm{NCH}_{2}\right), 3.00,2.58(2 \mathrm{t}, 4 \mathrm{H}, J=8.1 \mathrm{~Hz}$, $\left.2 \mathrm{CH}_{2}\right), 2.72\left(\mathrm{~s}, 3 \mathrm{H}, \mathrm{CH}_{3}\right), 2.35\left(\mathrm{~s}, 3 \mathrm{H}, \mathrm{CH}_{3}\right) ;{ }^{13} \mathrm{C}-\mathrm{NMR}$ (DMSO- $\left.d_{6}\right): 17.14,19.54,22.32,26.07,47.14,88.57$, 125.12, 128.61, 128.90, 131.28, 134.25(2 Ar-C), 135.71, 141.42, 147.14, 165.59, 197.14; MS m/z $360\left(\mathrm{M}^{+}\right.$, 6.99), 308 (10.72), 262 (100), 235 (43.02), 172 (28.69), 97 (47.44). Found: C, 56.62; H, 4.79; Cl, 9.85; N, 15.49\%. Calcd for $\mathrm{C}_{17} \mathrm{H}_{17} \mathrm{ClN}_{4} \mathrm{O}_{3}: \mathrm{C}, 56.59 ; \mathrm{H}, 4.75 ; \mathrm{Cl}, 9.83 ; \mathrm{N}, 15.53 \%$.

6-(4-Chloro-3-methylphenyl)-2-(2-oxo-2-(5-oxo-3-phenyl-2H-pyrazol-1(5H)-yl)ethyl)-4,5-dihydropyridazin -3(2H)-one (7). This compound was obtained as white crystals (ethanol) in $2.70 \mathrm{~g}(64 \%), \mathrm{mp} 258-260{ }^{\circ} \mathrm{C}$; IR $\left(\mathrm{KBr} \mathrm{cm}{ }^{-1}\right): 3312(\mathrm{NH}), 1669,1648(\mathrm{C}=\mathrm{O}) ;{ }^{1} \mathrm{H}-\mathrm{NMR}\left(\mathrm{DMSO}-d_{6}\right): \delta 9.09\left(\mathrm{~s}, 1 \mathrm{H}, \mathrm{OH} \mathrm{D}_{2} \mathrm{O}\right.$ exchangeable), 7.40-7.75 (m, 9H, 8Ar-H,1H pyrazolo), $4.31\left(\mathrm{~s}, 2 \mathrm{H}, \mathrm{NCH}_{2}\right), 4.24(\mathrm{~s}, 1 \mathrm{H}, \mathrm{NH}), 3.01,2.55$ $\left(2 \mathrm{t}, 4 \mathrm{H}, J=8.4 \mathrm{~Hz}, 2 \mathrm{CH}_{2}\right.$ ring), $2.36\left(\mathrm{~s}, 3 \mathrm{H}, \mathrm{CH}_{3}\right) ;{ }^{13} \mathrm{C}-\mathrm{NMR}$ (DMSO- $\left.d_{6}\right): 19.60,22.32,26.10,50.18,87.02$, 124.61, 125.07, 125.86, 128.50 (2Ar-C), 128.95 (2Ar-C), 131.29, 133.75, 134.33, 134.47, 135.56, 136.86, 149.17, 149.62, 165.57, 166.83; MS m/z 422 ( $\left.\mathrm{M}^{+}, 0.07\right), 294$ (26.80), 263 (72.94), 235 (100), 55 925.48). Found: $\mathrm{C}, 62.46 ; \mathrm{H}, 4.45 ; \mathrm{Cl}, 8.31 ; \mathrm{N}, 13.28 \%$. Calcd for $\mathrm{C}_{22} \mathrm{H}_{19} \mathrm{ClN}_{4} \mathrm{O}_{3}: \mathrm{C}, 62.49 ; \mathrm{H}, 4.53 ; \mathrm{Cl}, 8.38$; $\mathrm{N}, 13.25 \%$.

\subsubsection{General Procedure for Synthesizing Compounds $\mathbf{8}$ and 9}

The acetohydrazide $3(0.01 \mathrm{~mol}, 2.94 \mathrm{~g})$ was fused with excess ethyl cyanoacetate at $\sim 210^{\circ} \mathrm{C}$ in an oil-bath for $40 \mathrm{~min}$. Excess ethyl cyanoacetate was evaporated. The solid product was triturated with ethanol $(20 \mathrm{~mL})$ then filtered. The remained solid was crystallized to give 9 , and the ethanolic filtrate was poured onto crushed ice. The separated solid was filtered off, dried and recrystallized to give 8.

2-(3-(4-Chloro-3-methylphenyl)-6-oxo-5,6-dihydropyridazin-1(4H)-yl)-N'-(2-cyanoacet-yl)acetohydrazide (8). This compound was obtained as white crystals $(\mathrm{EtOH})$ in $1.59 \mathrm{~g}(46 \%), \mathrm{mp} 299-301{ }^{\circ} \mathrm{C}$; $\mathrm{IR}\left(\mathrm{KBr} \mathrm{cm}^{-1}\right)$ : $3182(\mathrm{NH}), 2212(\mathrm{C} \equiv \mathrm{N}), 1673,1657,1628(\mathrm{C}=\mathrm{O}) ;{ }^{1} \mathrm{H}-\mathrm{NMR}$ (DMSO- $\left.d_{6}\right): \delta 9.89,9.44(2 \mathrm{br} . \mathrm{s}, 2 \mathrm{H}, 2 \mathrm{NH}$ $\mathrm{D}_{2} \mathrm{O}$ exchangeable), 7.15-7.75 (m, 3H, Ar-H), $4.95\left(\mathrm{~s}, 2 \mathrm{H}, \mathrm{NCH}_{2} \mathrm{CO}\right), 4.33\left(\mathrm{~s}, 2 \mathrm{H}, \mathrm{CH}_{2} \mathrm{CN}\right), 2.99,2.56$ (2t, $4 \mathrm{H}, J=8.4,8.1 \mathrm{~Hz}, 2 \mathrm{CH}_{2}$ ring), $2.34\left(\mathrm{~s}, 3 \mathrm{H}, \mathrm{CH}_{3}\right) ;{ }^{13} \mathrm{C}-\mathrm{NMR}$ (DMSO- $d_{6}$ ): 15.24, 22.36, 25.74, 25.74, $27.14,114.2,127.40,128.96,131.42,132.85,134.28$ (2Ar-C), 148.45, 162.11, 170.00 (2CO); MS m/z 361 
$\left(\mathrm{M}^{+}, 2.67\right), 235$ (100), 222 (16.17), 141 (13.85). Found: C, 53.20; H, 4.42; Cl, 9.76; N, 19.54\%. Calcd for $\mathrm{C}_{16} \mathrm{H}_{16} \mathrm{ClN}_{5} \mathrm{O}_{3}: \mathrm{C}, 53.12 ; \mathrm{H}, 4.46 ; \mathrm{Cl}, 9.80 ; \mathrm{N}, 19.36 \%$.

2-(5-((3-(4-Chloro-3-methylphenyl)-6-oxo-5,6-dihydropyridazin-1(4H)-yl)methylene)-4,5-dihydro-1,3,4-oxad iazol-2-yl)acetonitrile (9). This compound was obtained as brown crystals (DMF) in $1.17 \mathrm{~g}(50 \%)$, $\mathrm{mp}>300^{\circ} \mathrm{C}$; IR $\left(\mathrm{KBr} \mathrm{cm}^{-1}\right): 3207(\mathrm{NH}), 2206(\mathrm{C} \equiv \mathrm{N}), 1664(\mathrm{C}=\mathrm{O}) ;{ }^{1} \mathrm{H}-\mathrm{NMR}$ (DMSO- $\left.d_{6}\right): \delta 9.99$ (br.s, $1 \mathrm{H}, \mathrm{NH} \mathrm{D}_{2} \mathrm{O}$ exchangeable), 7.38-7.75 (m, 4H, 3Ar-H, $\left.1 \mathrm{HC}=\right), 4.41\left(\mathrm{~s}, 2 \mathrm{H}, \mathrm{CH}_{2} \mathrm{CN}\right), 3.01,2.58(2 \mathrm{t}, 4 \mathrm{H}$, $J=8.4 \mathrm{~Hz}, 2 \mathrm{CH}_{2}$ ring), 2.35 (s, 3H, $\left.\mathrm{CH}_{3}\right) ;{ }^{13} \mathrm{C}-\mathrm{NMR}$ (DMSO-d 6 ): 14.03, 19.60, 23.92, 32.51, 60.75, 120.14, 128.60, 128.93, 129.65, 131.27, 134.25, 135.57, 149.76, 158.84, 172.18, 175.26; MS m/z $343\left(\mathrm{M}^{+}, 12.07\right), 123$ (20.53), 55 (100). Found: $\mathrm{C}, 55.67 ; \mathrm{H}, 4.12 ; \mathrm{Cl}, 10.26 ; \mathrm{N}, 20.54 \%$. Calcd for $\mathrm{C}_{16} \mathrm{H}_{14} \mathrm{ClN}_{5} \mathrm{O}_{2}: \mathrm{C}, 55.90 ; \mathrm{H}$, $4.10 ; \mathrm{Cl}, 10.31 ; \mathrm{N}, 20.37 \%$.

\subsubsection{Another Method for Synthesizing Compound 8}

A mixture of acetohydrazide $3(0.01 \mathrm{~mol}, 2.94 \mathrm{~g})$, ethyl cyanoacetate $(0.01 \mathrm{~mol}, 1.13 \mathrm{~mL})$ and drops of piperidine was refluxed in ethanol $(20 \mathrm{~mL})$ for $6 \mathrm{~h}$. The separated solid after cooling was filtered off, dried and recrystallized from ethanol to give compound 8.

\subsubsection{Another Method for Synthesizing Compound (9)}

Compound 8 was refluxed in ethanol for $3 \mathrm{~h}$. The reaction mixture was evaporated and the separated solid was filtered off, dried and recrystallized to give 9.

\subsubsection{General Procedure for Synthesizing Compounds 10-13}

To a stirred suspension of finely powdered potassium hydroxide $(0.02 \mathrm{~mol}, 1.12 \mathrm{~g})$ in dry DMF $(10 \mathrm{~mL})$ compound 8 or $\mathbf{9}(0.01 \mathrm{~mol})$ was added. The resulted mixture was cooled at $10{ }^{\circ} \mathrm{C}$ in an ice bath and then carbon disulfide $(0.50 \mathrm{~mL}, 0.01 \mathrm{~mol})$ was added slowly over the course of $10 \mathrm{~min}$. After complete addition, stirring of the reaction mixture was continued for additional $2 \mathrm{~h}$. Then dimethylsulfate or dibromoethane $(0.01 \mathrm{~mol})$ was added to the mixture while cooling $\left(\sim 15^{\circ} \mathrm{C}\right)$ and stirring for $1 \mathrm{~h}$. then poured onto crushed ice, the resulting precipitate was filtrated off, dried and crystallized from the proper solvent to give compounds 10-13 respectively.

$N^{\prime}$-(2-(3-(4-Chloro-3-methylphenyl)-6-oxo-5,6-dihydropyridazin-1(4H)-yl)acetyl)-2-cyano-3,3-bis(methylthio) acrylohydrazide (10). This compound was obtained as pale brown crystals (methanol) in $3.25 \mathrm{~g}(70 \%)$, $\mathrm{mp}>300{ }^{\circ} \mathrm{C}$; IR $\left(\mathrm{KBr} \mathrm{cm}^{-1}\right): 3220(\mathrm{NH}), 2204(\mathrm{C} \equiv \mathrm{N}), 1675(\mathrm{C}=\mathrm{O}) ;{ }^{1} \mathrm{H}-\mathrm{NMR}$ (DMSO- $\left.d_{6}\right): \delta 9.97$ (br.s, $2 \mathrm{H}, 2 \mathrm{NH} \mathrm{D}_{2} \mathrm{O}$ exchangeable), 7.43-7.75 (m, 3H, Ar- $\left.\mathrm{H}\right), 4.40\left(\mathrm{~s}, 2 \mathrm{H}, \mathrm{CH}_{2} \mathrm{~N}\right), 3.04,2.55(2 \mathrm{t}, 4 \mathrm{H}, J=8.1$, $8.4 \mathrm{~Hz}, 2 \mathrm{CH}_{2}$ ring), $2.89\left(\mathrm{~s}, 6 \mathrm{H}, 2 \mathrm{SCH}_{3}\right), 2.35\left(\mathrm{~s}, 3 \mathrm{H}, \mathrm{CH}_{3}\right) ;{ }^{13} \mathrm{C}-\mathrm{NMR}$ (DMSO- $\left.d_{6}\right): 14.24,19.60\left(2 \mathrm{CH}_{3}\right)$, 22.38, 26.05, 57.14, 78.57, 117.14, 128.93, 129.09, 131.42, 132.85, 134.79, 135.69, 146.60, 162.85, 165.89, 170.00, 175.71; MS m/z $465\left(\mathrm{M}^{+}, 0.00\right), 450$ (0.20), 418 (0.37), 71 (80.44), 57 (100). Found: C, 48.67; H, 4.39; $\mathrm{Cl}, 7.78 ; \mathrm{N}, 15.13 ; \mathrm{S}, 13.58 \%$. Calcd for $\mathrm{C}_{19} \mathrm{H}_{20} \mathrm{ClN}_{5} \mathrm{O}_{3} \mathrm{~S}_{2}: \mathrm{C}, 48.97 ; \mathrm{H}, 4.33 ; \mathrm{Cl}, 7.61 ; \mathrm{N}, 15.03 ; \mathrm{S}, 13.76 \%$.

2-(5-((3-(4-Chloro-3-methylphenyl)-6-oxo-5,6-dihydropyridazin-1(4H)-yl)methylene)-4,5-dihydro-1,3,4-oxad iazol-2-yl)-3,3-bis(methylthio)acrylonitrile (11). This compound was obtained as brown crystals (acetic acid) in $3.57 \mathrm{~g}(80 \%), \mathrm{mp}>300{ }^{\circ} \mathrm{C}$; IR $\left(\mathrm{KBr} \mathrm{cm}^{-1}\right)$ : $3327(\mathrm{NH}), 2207(\mathrm{C} \equiv \mathrm{N}), 1642(\mathrm{C}=\mathrm{O}), 1627$ $(\mathrm{C}=\mathrm{N}) ;{ }^{1} \mathrm{H}-\mathrm{NMR}$ (DMSO- $\left.d_{6}\right): \delta 9.99$ (br.s, $1 \mathrm{H}, \mathrm{NH} \mathrm{D}_{2} \mathrm{O}$ exchangeable), 6.93-8.12 (m, 4H, 3Ar-H, $1 \mathrm{HC}=$ oxadiazole $), 3.00,2.54\left(2 \mathrm{t}, 4 \mathrm{H}, J=8.4 \mathrm{~Hz}, 2 \mathrm{CH}_{2}\right.$ ring $), 2.88\left(\mathrm{~s}, 6 \mathrm{H}, 2 \mathrm{SCH}_{3}\right), 2.34\left(\mathrm{~s}, 3 \mathrm{H}, \mathrm{CH}_{3}\right)$; ${ }^{13} \mathrm{C}-\mathrm{NMR}$ (DMSO- $\left.d_{6}\right): 14.03,17.32\left(2 \mathrm{CH}_{3}\right), 23.83,31.42,67.97,76.32,116.21,127.40,128.85,129.63$, 131.29, 134.54, 135.64, 146.51, 158.21, 171.64, 171.90, 173.91; MS m/z $447\left(\mathrm{M}^{+}, 0.18\right), 432$ (0.32), 353 (0.25), 71 (81.61), 57 (100). Found: $\mathrm{C}, 50.83 ; \mathrm{H}, 4.96 ; \mathrm{Cl}, 7.98 ; \mathrm{N}, 15.13 ; \mathrm{S}, 14.22 \%$. Calcd for $\mathrm{C}_{19} \mathrm{H}_{18} \mathrm{ClN}_{5} \mathrm{O}_{2} \mathrm{~S}_{2}$ : C, 50.94; $\mathrm{H}, 4.05 ; \mathrm{Cl}, 7.91 ; \mathrm{N}, 15.63 ; \mathrm{S}, 14.32 \%$.

N'-(2-(3-(4-Chloro-3-methylphenyl)-6-oxo-5,6-dihydropyridazin-1(4H)-yl)acetyl)-2-cyano(1,3-dithiolan-2-ylid ene)acetohydrazide (12). This compound was obtained as pale brown crystals (dioxane) in $3.00 \mathrm{~g}$ $(65 \%), \mathrm{mp}>300{ }^{\circ} \mathrm{C}$; IR $\left(\mathrm{KBr} \mathrm{cm}^{-1}\right): 3436(\mathrm{NH}), 2206(\mathrm{C} \equiv \mathrm{N}), 1656,1646(\mathrm{C}=\mathrm{O}), 1625(\mathrm{C}=\mathrm{N}) ;{ }^{1} \mathrm{H}-\mathrm{NMR}$ 
(DMSO- $d_{6}$ ): $\delta 10.20$ (br.s, $1 \mathrm{H}, \mathrm{NH} \mathrm{D} \mathrm{D}_{2} \mathrm{O}$ exchangeable), 9.98 (s, 1H, NH D $2 \mathrm{O}$ exchangeable), 7.38-7.75 (m, 3H, 3Ar-H), 4.41 (s, 2H, CH ring), $2.35\left(\mathrm{~s}, 3 \mathrm{H}, \mathrm{CH}_{3}\right) ;{ }^{13} \mathrm{C}-\mathrm{NMR}\left(\mathrm{DMSO}-d_{6}\right): 14.67,25.97,26.10,34.28\left(2 \mathrm{CH}_{2} \mathrm{~S}\right), 52.80,81.40,118.13$, $127.83,128.93,130.32,132.68,135.49,135.56,149.55,164.73,165.86,169.87,179.57 ; \mathrm{MS} m / z 463\left(\mathrm{M}^{+}\right.$, 6.10), 368 (31.25), 297 (21.59), 270 (100), 185 (63.94) 55 (53.34). Found: C, 49.26; H, 3.89; Cl, 7.63; N, 15.16; S, 13.85\%. Calcd for $\mathrm{C}_{19} \mathrm{H}_{18} \mathrm{ClN}_{5} \mathrm{O}_{3} \mathrm{~S}_{2}$ : C, 49.19; $\mathrm{H}, 3.91 ; \mathrm{Cl}, 7.64 ; \mathrm{N}, 15.09 ; \mathrm{S}, 13.82 \%$.

2-(5-((3-(4-Chloro-3-methylphenyl)-6-oxo-5,6-dihydropyridazin-1(4H)-yl)methylene)-4,5-dihydro-1,3,4-oxad iazol-2-yl)-2-(1,3-dithiolan-2-ylidene)acetonitrile (13). This compound was obtained as brown crystals (dioxane) in $3.00 \mathrm{~g}(68 \%)$, mp $119-120{ }^{\circ} \mathrm{C}$; IR $\left(\mathrm{KBr} \mathrm{cm}^{-1}\right): 3200(\mathrm{NH}), 2214(\mathrm{C} \equiv \mathrm{N}), 1677(\mathrm{C}=\mathrm{O}) ;{ }^{1} \mathrm{H}-\mathrm{NMR}$ (DMSO-d $\left.d_{6}\right): \delta 10.00$ (br.s, $1 \mathrm{H}, \mathrm{NH} \mathrm{D} \mathrm{D}_{2} \mathrm{O}$ exchangeable), 7.43-7.95 (m, 4H, 3Ar-H, 1HC= oxadiazole), $\left.4.41\left(\mathrm{~s}, 4 \mathrm{H}, 2 \mathrm{SCH}_{2}\right), 2.89,2.60\left(2 \mathrm{t}, 4 \mathrm{H}, \mathrm{J}=8.1 \mathrm{~Hz}, 2 \mathrm{CH}_{2} \operatorname{ring}\right), 2.34\left(\mathrm{~s}, 3 \mathrm{H}, \mathrm{CH}_{3}\right) ;\right) ;{ }^{13} \mathrm{C}-\mathrm{NMR}\left(\mathrm{DMSO}-d_{6}\right)$ : 19.57, 26.10, 30.79, 35.80 (2CH2S), 68.57, 72.85, 112.85, 128.62, 128.93, 130.00, 131.42, 134.54, 135.63, 144.28, 162.34, 166.51, 174.28, 184.28; MS m/z $445\left(\mathrm{M}^{+}, 0.57\right), 235$ (76.08), 77 (100). Found: C, 51.15; $\mathrm{H}, 3.60 ; \mathrm{Cl}, 7.92 ; \mathrm{N}, 15.69 ; \mathrm{S}, 14.37 \%$. Calcd for $\mathrm{C}_{19} \mathrm{H}_{16} \mathrm{ClN}_{5} \mathrm{O}_{2} \mathrm{~S}_{2}$ : C, 51.17; H, 3.62; Cl, 7.95; N, 15.70; S, $14.38 \%$.

\subsubsection{General Procedure for Synthesizing Compounds 14 and 15}

To suspension of potassium hydroxide $(0.01 \mathrm{~mol}, 0.56 \mathrm{~g})$ in dry DMF $(10 \mathrm{~mL})$ compounds 8 or 9 $(0.01 \mathrm{~mol})$ was added during stirring, phenyl isothiocyanate $(0.01 \mathrm{~mol}, 1.20 \mathrm{~mL})$ was dropped slowly to the reaction mixture. After complete of addition, stirring of the reaction mixture was continued for $5 \mathrm{~h}$. and dimethyl sulfate $(0.01 \mathrm{~mol}, 0.94 \mathrm{~mL})$ was added. The reaction mixture was stirred for $2 \mathrm{~h}$. then, poured onto crushed ice. The resulting precipitate was filtered off, dried and recrystallized from the proper solvent to give 14 or 15.

N'-(2-(3-(4-chloro-3-methylphenyl)-6-oxo-5,6-dihydropyridazin-1(4H)-yl)acetyl)-2-cyano-3-(methylthio)-3(phenylamino)acrylohydrazide (14). This compound was obtained as brown crystals (ethanol) in $6.3 \mathrm{~g}$ $(72 \%), \mathrm{mp}>300{ }^{\circ} \mathrm{C}$; IR $\left(\mathrm{KBr} \mathrm{cm}^{-1}\right)$ : $3182(\mathrm{NH}), 2203(\mathrm{C} \equiv \mathrm{N}), 1673 \mathrm{br}(\mathrm{C}=\mathrm{O}$ broad $) ;{ }^{1} \mathrm{H}-\mathrm{NMR}\left(\mathrm{DMSO}-d_{6}\right)$ : $\delta 10.59,10.27,10.07$ (three br.s, 3H, 3NH D $2 \mathrm{O}$ exchangeable), 6.92-8.71 (m, 8H, Ar-H), 4.41 (s, $2 \mathrm{H}$, $\left.\mathrm{CH}_{2} \mathrm{CO}\right), 3.00,2.75\left(2 \mathrm{t}, 4 \mathrm{H}, J=8.4 \mathrm{~Hz}, 2 \mathrm{CH}_{2} \mathrm{ring}\right), 2.58\left(\mathrm{~s}, 3 \mathrm{H}, \mathrm{SCH}_{3}\right), 2.36\left(\mathrm{~s}, 3 \mathrm{H}, \mathrm{CH}_{3}\right) ;{ }^{13} \mathrm{C}-\mathrm{NMR}$ (DMSO- $\left.d_{6}\right): 14.24,15.30,23.60,26.10,53.18,70.63,115.21,116.50$ (2Ar-C), 118.35, 127.41, 128.85, 129.72 (2Ar-C), 137.03, 135.71, 131.41, 132.63, 144.56, 146.44, 162.54, 165.62, 170.31, 177.14; MS m/z $511\left(\mathrm{M}^{+}\right.$, 0.00), 496 (0.72), 439 (15.10), 425 (100), 263 (10.30), 235 (29.40), 135 (44.93), 63 (46.51). Found: C, 56.57; $\mathrm{H}, 4.58 ; \mathrm{Cl}, 6.77 ; \mathrm{N}, 16.63 ; \mathrm{S}, 6.35 \%$. Calcd for $\mathrm{C}_{24} \mathrm{H}_{23} \mathrm{ClN}_{6} \mathrm{O}_{3} \mathrm{~S}: \mathrm{C}, 56.41 ; \mathrm{H}, 4.54 ; \mathrm{Cl}, 6.94 ; \mathrm{N}, 16.45$; $\mathrm{S}, 6.28 \%$.

2-5-((3-(4-Chloro-3-methylphenyl)-6-oxo-5,6-dihydropyridazin-1(4H)-yl)methylene)-4,5-dihydro-1,3,4-oxad iazol-2-yl)-3-(methylthio)-3-(phenylamino)acrylonitrile (15). This compound was obtained as brown crystals (acetic acid) in $3.88 \mathrm{~g}(79 \%), \mathrm{mp}>300^{\circ} \mathrm{C}$; IR $\left(\mathrm{KBr} \mathrm{cm}^{-1}\right): 3333,3211(\mathrm{NH}), 2202(\mathrm{C} \equiv \mathrm{N}), 1714$ $(\mathrm{C}=\mathrm{O}) ;{ }^{1} \mathrm{H}-\mathrm{NMR}$ (DMSO- $\left.d_{6}\right): \delta 8.62,7.57$ (2br.s, 2H, 2NH D $2 \mathrm{O}$ exchangeable), 7.27-7.73 (m, 8H, Ar-H), $6.96(\mathrm{~s}, 1 \mathrm{H},=\mathrm{CH}), 3.00,2.67\left(2 \mathrm{t}, 4 \mathrm{H}, \mathrm{J}=8.1 \mathrm{~Hz}, 2 \mathrm{CH}_{2} \operatorname{ring}\right), 2.41\left(\mathrm{~s}, 3 \mathrm{H}, \mathrm{SCH}_{3}\right), 2.34\left(\mathrm{~s}, 3 \mathrm{H}, \mathrm{CH}_{3}\right)$; ${ }^{13}$ C-NMR (DMSO- $d_{6}$ ): 14.03, 15.90, 22.82, 32.51, 65.28, 68.56, 115.87, 116.01 (2Ar-C), 118.27, 127.37, $128.64,129.52$ (2Ar-C), 130.59, 132.71, 136.25, 135.57, 144.41, 146.20, 156.28, 170.98, 172.19, 173.64; Found: C, 58.30; H, 4.28; Cl, 7.22; N, 16.97; S, 6.47\%. Calcd for $\mathrm{C}_{24} \mathrm{H}_{21} \mathrm{ClN}_{6} \mathrm{O}_{2} \mathrm{~S}: \mathrm{C}, 58.47 ; \mathrm{H}, 4.29 ; \mathrm{Cl}$, $7.19 ; \mathrm{N}, 17.05 ; \mathrm{S}, 6.50 \%$.

3.2.10. 2-(3-(4-Chloro-3-methylphenyl)-6-oxo-5,6-dihydropyridazin-1(4H)-yl)-N-(3-cyano4,6-dimethyl-2-oxopyridin-1(2H)-yl)acetamide (16)

A mixture of compound $8(0.01 \mathrm{~mol}, 3.61 \mathrm{~g})$, acetylacetone $(0.012 \mathrm{~mol}, 1.1 \mathrm{~mL})$ and piperidine (few drops) in ethanol (20 mL) was refluxed for $6 \mathrm{~h}$. The obtained solid was collected by filtration, dried and recrystallized from ethanol as brown crystals in $2.6 \mathrm{~g}(63 \%), \mathrm{mp}>300{ }^{\circ} \mathrm{C}$; $\mathrm{IR}\left(\mathrm{KBr} \mathrm{cm}^{-1}\right): 3180(\mathrm{NH})$, $2214(\mathrm{C} \equiv \mathrm{N}), 1677,1657,1642(\mathrm{C}=\mathrm{O}) ;{ }^{1} \mathrm{H}-\mathrm{NMR}\left(\mathrm{DMSO}-d_{6}\right): \delta 9.99$ (br.s, $1 \mathrm{H}, \mathrm{NH} \mathrm{D} \mathrm{D}_{2} \mathrm{O}$ exchangeable), 
7.38-7.75 (m, 4H, 3Ar-H, 1HC=), $4.41\left(\mathrm{~s}, 2 \mathrm{H}, \mathrm{CH}_{2} \mathrm{~N}\right), 3.01,2.58\left(2 \mathrm{t}, 4 \mathrm{H}, \mathrm{J}=8.4,8.1 \mathrm{~Hz}, 2 \mathrm{CH}_{2}\right.$ ring $), 2.35$ $\left.\left(\mathrm{s}, 6 \mathrm{H}, 2 \mathrm{CH}_{3}\right), 2.28\left(\mathrm{~s}, 3 \mathrm{H}, \mathrm{CH}_{3}\right)\right) ;{ }^{13} \mathrm{C}-\mathrm{NMR}\left(\mathrm{DMSO}-d_{6}\right): 15.7\left(2 \mathrm{CH}_{3}\right), 19.45,22.32,26.08,54.28,108.57$, 114.28, 115.71, 125.11, 128.57, 131.42, 132.85, 134.24, 135.71 (2Ar-C), 146.45, 152.85, 158.57, 165.61, 166.47; MS m/z $425\left(\mathrm{M}^{+}, 0.00\right), 427(\mathrm{M}+2,1.31), 322$ (3.80), 149 (15.82), 111 (25.78), 97 (40.66), 57 (100). Found: C, 59.12; $\mathrm{H}, 4.89 ; \mathrm{Cl}, 8.40 ; \mathrm{N}, 16.59 \%$. Calcd for $\mathrm{C}_{21} \mathrm{H}_{20} \mathrm{ClN}_{5} \mathrm{O}_{3}: \mathrm{C}, 59.23 ; \mathrm{H}, 4.73 ; \mathrm{Cl}, 8.32 ; \mathrm{N}, 16.44 \%$.

\subsubsection{General Procedure for Synthesizing Compounds $\mathbf{1 7}$ and $\mathbf{1 8}$}

A mixture of compounds 8 and/or $9(0.01 \mathrm{~mol})$ and salicylaldehyde, $(1.07 \mathrm{~g}, 0.01 \mathrm{~mol})$ in ethanol $(30 \mathrm{~mL})$ containing ammonium acetate $(0.3 \mathrm{~g})$ was heated under reflux for $0.5 \mathrm{~h}$. The solvent was evaporated and the obtained solid product was filtered off and recrystallized from the proper solvent.

N'-(2-(3-(4-Chloro-3-methylphenyl)-6-oxo-5,6-dihydropyridazin-1(4H)-yl)acetyl)-2-cyano-3-(2-hydroxyphenyl) acrylohydrazide (17). This compound was obtained as brown crystals (acetic acid) in $3.16 \mathrm{~g}(68 \%)$, $\mathrm{mp}>300{ }^{\circ} \mathrm{C}$; IR $\left(\mathrm{KBr} \mathrm{cm}{ }^{-1}\right): 3414(\mathrm{OH}), 3188(\mathrm{NH}), 2206(\mathrm{C} \equiv \mathrm{N}), 1671,1653,1628(\mathrm{C}=\mathrm{O}$ broad); ${ }^{1} \mathrm{H}-\mathrm{NMR}$ (DMSO- $\left.d_{6}\right): \delta 9.99$ (br.s, 2H, 2NH D $\mathrm{D}_{2}$ exchangeable), $8.41(\mathrm{~s}, 1 \mathrm{H}, 1 \mathrm{HC}=\mathrm{C}), 7.38-7.75(\mathrm{~m}, 7 \mathrm{H}$, 3Ar-H), 7.18 (br.s, 1H, OH D $2 \mathrm{O}$ exchangeable), $4.41\left(\mathrm{~s}, 2 \mathrm{H}, \mathrm{CH}_{2} \mathrm{~N}\right), 3.01,2.58(2 \mathrm{t}, 4 \mathrm{H}, \mathrm{J}=8.4,8.1 \mathrm{~Hz}$, $2 \mathrm{CH}_{2}$ ring), 2.34 (s, 3H, $\left.\mathrm{CH}_{3}\right) ;{ }^{13} \mathrm{C}-\mathrm{NMR}$ (DMSO-d $): 19.55,22.32,26.06,54.28,111.12,115.90,116.10$, 118.80, 119.50, 127.14 (2Ar-C), 128.90, 129.28, 131.42, 132.85, 135.57, 138.12, 145.71, 154.28, 158.57, 161.42, 165.62, 171.42; MS m/z 465 (M $\left.\mathrm{M}^{+}, 0.22\right), 238$ (90.24), 164 (100). Found: C, 59.22; H, 4.25; Cl, 7.77; $\mathrm{N}, 15.12 \%$. Calcd for $\mathrm{C}_{23} \mathrm{H}_{20} \mathrm{ClN}_{5} \mathrm{O}_{4}$ : C, 59.29; $\mathrm{H}, 4.33 ; \mathrm{Cl}, 7.61 ; \mathrm{N}, 15.03 \%$.

2-(5-((3-(4-chloro-3-methylphenyl)-6-oxo-5,6-dihydropyridazin-1(4H)-yl)methylene)-4,5-dihydro-1,3,4-oxadiazol -2-yl)-3-(2-hydroxyphenyl)acrylonitrile (18). This compound was obtained as brown crystals (ethanol) in $3.39 \mathrm{~g}(76 \%), \mathrm{mp}>300{ }^{\circ} \mathrm{C}$; IR $\left(\mathrm{KBr} \mathrm{cm}^{-1}\right)$ : $3419(\mathrm{OH}), 3200(\mathrm{NH}), 2207(\mathrm{C} \equiv \mathrm{N}), 1671(\mathrm{C}=\mathrm{O}) ;{ }^{1} \mathrm{H}-\mathrm{NMR}$ $\left(\right.$ DMSO- $\left.d_{6}\right)$ : $\delta 9.97$ (br.s, $1 \mathrm{H}, \mathrm{NH} \mathrm{D} 2 \mathrm{O}$ exchangeable), 7.45-7.75 (m, 9H, 7Ar-H, 1HC=C, 1OH), $2.99,2.72$ $\left(2 \mathrm{t}, 4 \mathrm{H}, J=8.4,8.1 \mathrm{~Hz}, 2 \mathrm{CH}_{2}\right.$ ring), $2.35\left(\mathrm{~s}, 3 \mathrm{H}, \mathrm{CH}_{3}\right) ;{ }^{13} \mathrm{C}-\mathrm{NMR}$ (DMSO-d 6 ): 19.55, 26.08, 28.99, 67.14, $101.42,115.71$ (2Ar-C), 116.01, 121.42, 128.57, 128.59 (2Ar-C), 128.89, 134.23, 134.52, 135.57, 137.04, 140.80, 149.74, 155.87, 157.14, 165.61, 166.48; MS m/z $447\left(\mathrm{M}^{+}, 0.19\right), 337$ (0.78), 111 (34.25), 85 (56.42), 71 (69.22), 57 (100). Found: C, 61.57; H, 3.99; Cl, 7.89; N, 15.68\%. Calcd for $\mathrm{C}_{23} \mathrm{H}_{18} \mathrm{ClN}_{5} \mathrm{O}_{3}: \mathrm{C}, 61.68 ; \mathrm{H}$, $4.05 ; \mathrm{Cl}, 7.92 ; \mathrm{N}, 15.64 \%$.

\subsubsection{General Procedure for Synthesizing Compounds 19 and 20}

To a mixture of compounds 8 or $9(0.01 \mathrm{~mol}), p$-anisaldehyde $(0.01 \mathrm{~mol}, 1.22 \mathrm{~g})$ and malononitrile $(0.01 \mathrm{~mol}, 0.66 \mathrm{~g})$ in ethanol $(30 \mathrm{~mL})$, a few drops of piperidine were added. The reaction mixture was heated under reflux for $3 \mathrm{~h}$. The solid product which formed was collected by filtration while hot and recrystallized from the appropriate solvent to give 19 and 20.

N-(6-Amino-3,5-dicyano-4-(4-methoxyphenyl)-2-oxopyridin-1(2H)-yl)-2-(3-(4-chloro-3-methylphenyl)-6-oxo5,6-dihydropyridazin-1(4H)-yl)acetamide (19). This compound was obtained as brown crystals (acetic acid) in $3.47 \mathrm{~g}(64 \%), \mathrm{mp}>300^{\circ} \mathrm{C}$; IR $\left(\mathrm{KBr} \mathrm{cm}^{-1}\right): 3457,3271,3178\left(\mathrm{NH}_{2}, \mathrm{NH}\right), 2206(\mathrm{C} \equiv \mathrm{N}), 1676,1642$ $(\mathrm{C}=\mathrm{O}), 1623(\mathrm{C}=\mathrm{N}) ;{ }^{1} \mathrm{H}-\mathrm{NMR}\left(\mathrm{DMSO}-d_{6}\right): \delta 10.00$ (br.s, $1 \mathrm{H}, \mathrm{NH} \mathrm{D} \mathrm{O}_{2} \mathrm{O}$ exchangeable), 9.87 (br.s, $2 \mathrm{H}$, $\mathrm{NH}_{2} \mathrm{D}_{2} \mathrm{O}$ exchangeable), 7.11-7.97 (m, 7H, Ar-H), $4.47\left(\mathrm{~s}, 2 \mathrm{H}, \mathrm{CH}_{2} \mathrm{~N}\right), 3.87\left(\mathrm{~s}, 3 \mathrm{H}, \mathrm{OCH}_{3}\right), 2.98,2.55(2 \mathrm{t}$, $4 \mathrm{H}, J=8.4 \mathrm{~Hz}, 2 \mathrm{CH}_{2}$ ring), 2.35 (s, 3H, $\left.\mathrm{CH}_{3}\right) ;{ }^{13} \mathrm{C}-\mathrm{NMR}\left(\mathrm{DMSO}-d_{6}\right):$ 19.54, 22.20, 26.08, 54.28, 55.68, 75.71, $113.78(2 \mathrm{Ar}-\mathrm{C}), 114.50(2 \mathrm{C} \equiv \mathrm{N}), 114.60,122.85,125.11(2 \mathrm{Ar}-\mathrm{C}), 128.59,128.90,131.79,132.85$, 134.28, 135.71, 145.71, 152.85, 161.42, 164.28, 165.71, 170.00, 191.30; MS m/z $543\left(\mathrm{M}^{+}, 0.16\right), 235$ (100), 221 (29.80), 57 (38.20). Found: C, 59.59; H, 4.09; Cl, 6.48; N, 18.10\%. Calcd for $\mathrm{C}_{27} \mathrm{H}_{22} \mathrm{ClN}_{7} \mathrm{O}_{4}$ : C, 59.62; $\mathrm{H}, 4.08 ; \mathrm{Cl}, 6.52 ; \mathrm{N}, 18.02 \%$.

5-Amino-2-((3-(4-chloro-3-methylphenyl)-6-oxo-5,6-dihydropyridazin-1(4H)-yl)methylene)-7-(4-methoxyphenyl) -3,7-dihydro-2H-[1,3,4]oxadiazolo[3,2-a]pyridine-6,8-dicarbonitrile (20). This compound was obtained as brown crystals $(\mathrm{EtOH})$ in $3.05 \mathrm{~g}(58 \%), \mathrm{mp} 198-200^{\circ} \mathrm{C}$; IR $\left(\mathrm{KBr} \mathrm{cm}^{-1}\right): 3448,3178\left(\mathrm{NH}_{2}, \mathrm{NH}\right), 2206$ $(\mathrm{C} \equiv \mathrm{N}), 1674(\mathrm{C}=\mathrm{O}) ;{ }^{1} \mathrm{H}-\mathrm{NMR}\left(\mathrm{DMSO}-d_{6}\right): \delta 8.40$ (br.s, $1 \mathrm{H}, \mathrm{NH} \mathrm{D} \mathrm{D}_{2} \mathrm{O}$ exchangeable), 6.95-7.71 (m, 7H, 
$\mathrm{Ar}-\mathrm{H}), 5.07(\mathrm{~s}, 1 \mathrm{H},=\mathrm{CH}), 4.41(\mathrm{~s}, 1 \mathrm{H}, \mathrm{CH}), 3.74\left(\mathrm{~s}, 3 \mathrm{H}, \mathrm{OCH}_{3}\right), 3.02,2.60\left(2 \mathrm{t}, 4 \mathrm{H}, J=8.4,8.1 \mathrm{~Hz}_{2} \mathrm{CH}_{2}\right.$ ring), 2.72 (br.s, $2 \mathrm{H}, \mathrm{NH}_{2} \mathrm{D}_{2} \mathrm{O}$ exchangeable), 2.72 (s, 3H, $\left.\mathrm{CH}_{3}\right) ;{ }^{13} \mathrm{C}-\mathrm{NMR}$ (DMSO- $\left.d_{6}\right): 15.49,22.90$, $32.48,37.51,55.92,56.80,57.79,72.94,114.62,(2 \mathrm{Ar}-\mathrm{C}), 117.25(2 \mathrm{C} \equiv \mathrm{N}), 127.54,128.82,130.21(2 \mathrm{Ar}-\mathrm{C})$, 131.24, 132.30, 134.72, 136.37, 136.92, 144.05, 146.48, 154.28, 160.85, 166.47, 170.03; MS m/z $527\left(\mathrm{M}^{+}\right.$, 2.58), 480 (37.37), 368 (25.21), 278 (41.76), 263 (52.49), 235 (100), 121 (43.93), 55 (60.27). Found: C, 61.46; $\mathrm{H}, 3.99 ; \mathrm{Cl}, 6.80 ; \mathrm{N}, 18.59 \%$. Calcd for $\mathrm{C}_{27} \mathrm{H}_{22} \mathrm{ClN}_{7} \mathrm{O}_{3}: \mathrm{C}, 61.42 ; \mathrm{H}, 4.20 ; \mathrm{Cl}, 6.72 ; \mathrm{N}, 18.57 \%$.

\subsubsection{2-(6-((3-(4-Chloro-3-methylphenyl)-6-oxo-5,6-dihydropyridazin-1(4H)-yl)} methyl)-1,2-dihydro-1,2,4,5-tetrazin-3-yl)acetonitrile (21)

A mixture of compound $8(0.01 \mathrm{~mol}, 3.61 \mathrm{~g})$ and hydrazine hydrate $(0.01 \mathrm{~mol}, 0.50 \mathrm{~mL})$ in ethanol $(20 \mathrm{~mL})$ was refluxed for $3 \mathrm{~h}$. The separated solid was filtered off, dried and recrystallized from benzene as brown crystals in $2.82 \mathrm{~g}(79 \%), \mathrm{mp} 168-170{ }^{\circ} \mathrm{C}$; IR $\left(\mathrm{KBr} \mathrm{cm}^{-1}\right): 3312(\mathrm{NH}), 2199(\mathrm{C} \equiv \mathrm{N}), 1667(\mathrm{C}=\mathrm{O})$; ${ }^{1} \mathrm{H}-\mathrm{NMR}$ (DMSO- $d_{6}$ ): $\delta$ 10.47, 9.07 (two br.s, $2 \mathrm{H}, 2 \mathrm{NH} \mathrm{D}_{2} \mathrm{O}$ exchangeable), 7.35-7.71 (m, 3H, Ar-H), 4.31 (s, 2H, CH $2 \mathrm{~N}), 4.26\left(\mathrm{~s}, 2 \mathrm{H}, \mathrm{CH}_{2} \mathrm{CN}\right), 3.01,2.55\left(2 \mathrm{t}, 4 \mathrm{H}, \mathrm{J}=8.1,8.4 \mathrm{~Hz}, 2 \mathrm{CH}_{2} \mathrm{ring}\right), 2.36\left(\mathrm{~s}, 3 \mathrm{H}, \mathrm{CH}_{3}\right)$; ${ }^{13}$ C-NMR (DMSO-d $)$ ): 15.63, 18.20, 22.60, 29.31, 49.38, 115.97, 127.75, 128.82, 131.20, 132.11, 136.50, 136.72, 146.72, 162.37, $163.40(2 \mathrm{C}=\mathrm{N})$; MS m/z $357\left(\mathrm{M}^{+}, 27.99\right), 262$ (100), 172 (21.93), 97 (39.80). Found: C, 53.99; H, 4.12; Cl, 9.98; N, 27.37\%. Calcd for $\mathrm{C}_{16} \mathrm{H}_{16} \mathrm{ClN}_{7} \mathrm{O}: \mathrm{C}, 53.71 ; \mathrm{H}, 4.51 ; \mathrm{Cl}, 9.91 ; \mathrm{N}, 27.40 \%$.

\subsubsection{2-(5-((3-(4-Chloro-3-methylphenyl)-6-oxo-5,6-dihydropyridazin-1(4H)-yl)methyl)-4H-benzo[g]-} [1,3,4,6]-thiatriazocin-2-yl)acetonitrile (22)

A mixture of compound 8 (3.61 g, $0.01 \mathrm{~mol})$ and 2-amino thiophenol $(0.01 \mathrm{~mol}, 1.25 \mathrm{~mL})$ in DMF $(20 \mathrm{~mL})$ was refluxed for $3 \mathrm{~h}$. The reaction mixture was poured on water. The separated solid was filtered off, dried and recrystallized from ethanol as brown crystals in $1.89 \mathrm{~g}(42 \%), \mathrm{mp}>300{ }^{\circ} \mathrm{C}$; IR $\left(\mathrm{KBr} \mathrm{cm}^{-1}\right): 3328,3182(\mathrm{NH}), 2205(\mathrm{C} \equiv \mathrm{N}), 1660(\mathrm{C}=\mathrm{O}), 1612(\mathrm{C}=\mathrm{N}) ;{ }^{1} \mathrm{H}-\mathrm{NMR}\left(\mathrm{DMSO}-d_{6}\right): \delta 6.40-7.93$ (m, 7H, Ar-H), 5.44 (br.s, 1H, NH D $2 \mathrm{O}$ exchangeable), $4.39\left(\mathrm{~s}, 2 \mathrm{H}, \mathrm{CH}_{2} \mathrm{~N}\right), 2.95\left(\mathrm{~s}, 2 \mathrm{H}, \mathrm{CH}_{2} \mathrm{CN}\right), 2.86$, $2.71\left(2 \mathrm{t}, 4 \mathrm{H}, \mathrm{J}=8.4,8.1 \mathrm{~Hz}, 2 \mathrm{CH}_{2}\right.$ ring), 2.37 (s, 3H, $\left.\mathrm{CH}_{3}\right) ;{ }^{13} \mathrm{C}-\mathrm{NMR}\left(\mathrm{DMSO}-d_{6}\right): 15.24,19.99,23.40$, 26.89, 50.61, 115.89, 122.85, 124.30, 127.00, 127.54 (2Ar-C), 128.86, 130.53 (2Ar-C), 131.75, 136.48, 136.90, 146.52, 153.97, 154.01, 162.53, 163.76; MS m/z 450 ( $\left.\mathrm{M}^{+}, 0.06\right), 358$ (27.99), 262 (100) 172 (21.93), 97 (39.80). Found: C, 58.77; H, 4.28; Cl, 7.67; N, 18.73; S, 7.205. Calcd for $\mathrm{C}_{22} \mathrm{H}_{19} \mathrm{ClN}_{6} \mathrm{OS}$ : C, 58.60; $\mathrm{H}, 4.25 ; \mathrm{Cl}, 7.86$; $\mathrm{N}, 18.64 ; \mathrm{S}, 7.11 \%$.

\subsection{Pharmacological Activity}

\subsubsection{Cytotoxicity Assay}

The cytotoxic activity of twelve compounds was tested against four human tumor cell lines namely: hepatocellular carcinoma (liver) HePG-2, colon cancer HCT-116, human (prostate) cancer cell line PC3, and mammary gland (breast) MCF-7. The cell lines were obtained from the ATCC via the Holding Company for Biological Products and Vaccines (VACSERA, Cairo, Egypt). 5-Fluorouracil was used as a standard anticancer drug for comparison. The reagents used were RPMI-1640 medium, MTT, DMSO and 5-fluorouracil (Sigma Co., St. Louis, MO, USA), and Fetal Bovine Serum (GIBCO, Paisley, UK).

\section{MTT Assay}

The different cell lines [68,69] mentioned above were used to determine the inhibitory effects of compounds on cell growth using the MTT assay. This colorimetric assay is based on the conversion of the yellow tetrazolium bromide (MTT) to a purple formazan derivative by mitochondrial succinate dehydrogenase in viable cells. The cells were cultured in RPMI-1640 medium with 10\% fetal bovine serum. Antibiotics added were 100 units $/ \mathrm{mL}$ penicillin and $100 \mu \mathrm{g} / \mathrm{mL}$ streptomycin at $37^{\circ} \mathrm{C}$ in a $5 \%$ $\mathrm{CO}_{2}$ incubator. The cell lines were seeded [70] in a 96-well plate at a density of $1.0 \times 10^{4}$ cells / well at $37{ }^{\circ} \mathrm{C}$ for $48 \mathrm{~h}$ under $5 \% \mathrm{CO}_{2}$ incubator. After incubation the cells were treated with different 
concentration of compounds and incubated for $24 \mathrm{~h}$. After $24 \mathrm{~h}$ of drug treatment, $20 \mu \mathrm{L}$ of MTT solution at $5 \mathrm{mg} / \mathrm{mL}$ was added and incubated for $4 \mathrm{~h}$. Dimethyl sulfoxide (DMSO) in volume of 100 $\mu \mathrm{L}$ is added into each well to dissolve the purple formazan formed. The colorimetric assay is measured and recorded at absorbance of $570 \mathrm{~nm}$ using a plate reader (EXL 800, BioTech, Winoosky, VT, USA). The relative cell viability in percentage was calculated as $\left(A_{570}\right.$ of treated samples $/ A_{570}$ of untreated sample) $\times 100$.

\subsubsection{Antioxidant Assay}

\section{ABTS Method}

For each of the investigated compounds [71-73] ABTS solution (60 $\mu \mathrm{M}, 2 \mathrm{~mL})$ was added to $\mathrm{MnO}_{2}$ suspension ( $25 \mathrm{mg} / \mathrm{mL}, 3 \mathrm{~mL}$ ), all prepared in aqueous phosphate buffer solution ( $\mathrm{pH} 7,0.1 \mathrm{M}, 5 \mathrm{~mL}$ ). The mixture was shaken, centrifuged, filtered and the absorbance of the resulting green blue solution (ABTS radical solution) at $734 \mathrm{~nm}$ was adjusted to approx. $c a$. 0.5 . Then, a solution $(50 \mu \mathrm{L}, 2 \mathrm{mM})$ of the tested compound in spectroscopic grade $\mathrm{MeOH} /$ phosphate buffer (1:1) was added. The absorbance was measured and the reduction in color intensity was expressed as inhibition percentage. L-ascorbic acid was used as standard antioxidant (positive control). Blank sample was run without ABTS and using $\mathrm{MeOH} /$ phosphate buffer (1:1) instead of the tested compounds. Negative control was run with ABTS and $\mathrm{MeOH} /$ phosphate buffer (1:1) only.

Bleomycin-Dependent DNA Damage Assay

To the reaction mixtures $[74,75]$ in a final volume of $1.0 \mathrm{~mL}$, the following reagents were added: DNA $(0.2 \mathrm{mg} / \mathrm{mL})$, bleomycin sulfate $(0.05 \mathrm{mg} / \mathrm{mL}), \mathrm{FeCl}_{3}(0.025 \mathrm{mM})$, magnesium chloride $(5 \mathrm{mM})$, $\mathrm{KH}_{2} \mathrm{PO}_{4}-\mathrm{KOH}$ buffer $\mathrm{pH} 7.0(30 \mathrm{mM})$, and ascorbic acid $(0.24 \mathrm{mM})$ or the test fractions diluted in $\mathrm{MeOH}$ to give a concentration of $(0.1 \mathrm{mg} / \mathrm{mL})$. The reaction mixtures were incubated in a water bath at $37^{\circ} \mathrm{C}$ for $1 \mathrm{~h}$. At the end of the incubation period, $0.1 \mathrm{~mL}$ of ethylenediaminetetraacetic acid (EDTA) $(0.1 \mathrm{M})$ was added to stop the reaction (the iron-EDTA complex is unreactive in the bleomycin assay). DNA damage was assessed by adding $1 \mathrm{~mL} 1 \%(w / v)$ thiobarbituric acid (TBA) and $1 \mathrm{~mL}$ of 25\% (v/v) hydrochloric acid followed by heating in a water-bath maintained at $80^{\circ} \mathrm{C}$ for $15 \mathrm{~min}$. The chromogen formed was extracted into 1-butanol, and the absorbance was measured at $532 \mathrm{~nm}$.

\section{Conclusions}

In this work, the acetohydrazide reacted with excess ethyl cyanoacetate to afford cyanoacetylacetohydrazide and oxadiazolylacetonitrile derivatives. The latter compounds reacted with different nitrogen and carbon nucleophiles to give bis(methylthio), dithiolan-2-ylidene, methylthio-3-phenylamino, oxopyridine, hydroxyphenyl and tetrazine derivatives. Some of the newly prepared compounds were tested in vitro against a panel of four human tumor cell lines and also as antioxidants. Almost all of the tested compounds showed satisfactory activity. Compounds 8 and 21 showed activity towards MCF-7 and PC-3 cell line nearly equal to the 5-flurouracil, respectively. Also they showed very high \% inhibition nearly equal to the ascorbic acid. Hence, they could be potential drugs candidate for cancer treatment.

Supplementary Materials: Supplementary materials can be accessed at: http://www.mdpi.com/1420-3049/ 21/2/155/s1.

Acknowledgments: Technical support from Department of Chemistry, Faculty of Science, Ain Shams University is gratefully acknowledged.

Author Contributions: Soheir A. Shaker and Magda I. Marzouk contributed equally to this work.

Conflicts of Interest: The authors declare no conflict of interest. 


\section{References}

1. Youssef, A.S.; Marzouk, M.I.; Madkour, H.M.; El-Soll, A.M.; El-Hashash, M.A. Synthesis of some heterocyclic systems of anticipated biological activities via 6-aryl-4-pyrazol-1-yl-pyridazin-3-one. Can. J. Chem. 2005, 83, 251-259. [CrossRef]

2. Takaya, M.; Sato, M.; Terashima, K.; Tanizawa, H.; Maki, Y. A new nonsteroidal analgesic-anti-inflammatory agent. Synthesis and activity of 4-ethoxy-2-methyl-5-morpholino-3(2H)-pyridazinone and related compounds. J. Med. Chem. 1979, 22, 53-58. [CrossRef] [PubMed]

3. Şüküroğlu, M.; Çalışkan-Ergun, B.; Ünlü, S.; Sahin, M.F.; Küpeli, E.; Yeşilada, E.; Banoğlu, E. Synthesis, analgesic, and anti-inflammatory activities of [6-(3,5-dimethyl-4-chloropyrazole-1-yl)-3(2H)pyridazinon-2-yl]acetamides. Arch. Pharm. Res. 2005, 28, 509-517. [CrossRef] [PubMed]

4. Şüküroğlu, M.; Küpeli, E.; Banoğlu, E.; Ünlü, S.; Yeşilada, E.; Şahin, M.F. Synthesis and analgesic activity of some 4,6-disubstituted-3(2H)-pyridazinone derivatives. Arzneim. Forsch. Drug Res. 2006, 56, 337-345.

5. Özdemir, Z.; Gökçe, M.; Karakurt, A. Synthesis and analgesic, anti-inflammatory and antimicrobial evaluation of 6-substituted-3(2H)-pyridazinone-2-acetyl-2-(substituted benzal) hydrazone derivatives. Fabad J. Pharm. Sci. 2012, 37, 111-122.

6. Abouzid, K.A.M.; Khalil, N.A.; Ahmed, E.M.; Abd El-Latif, H.A.; El-Araby, M.E. Structure-based molecular design, synthesis, and in vivo anti-inflammatory activity of pyridazinone derivatives as nonclassic COX-2 inhibitors. Med. Chem. Res. 2010, 19, 629-642. [CrossRef]

7. Sonmez, M.; Berber, I.; Akbas, E. Synthesis, antibacterial and antifungal activity of some new pyridazinone metal complexes. Eur. J. Med. Chem. 2006, 41, 101-105. [CrossRef] [PubMed]

8. Doğruer, D.S.; Őnkol, T.S.; Őzkan, S.; Őzgen, S.; Şahin, M.F. Synthesis and antimicrobial activity of some 3(2H)-pyridazinone and 1(2H)-phthalazinone derivatives. Turk. J. Chem. 2008, 32, 469-479.

9. Kočar, T.; Rečnik, S.; Svete, J.; Stanovnik, B. Transformations of 3-aminopyridazines. Synthesis of 4-oxo-4H-pyrimido[1,2-b]pyridazine and 1-(substituted pyridazin-3-yl)-1H-1,2,3-triazole derivatives (AP-542HP). Arkivoc 2002, 2002, 143-156.

10. Ahmad, S.; Rathish, I.G.; Bano, S.; Alam, M.S.; Javed, K. Synthesis and biological evaluation of some novel 6-aryl-2-( $p$-sulfamylphenyl)-4,5-dihydropyridazin-3(2H)-ones as anti-cancer, antimicrobial, and anti-inflammatory agents. J. Enzym. Inhib. Med. Chem. 2010, 25, 266-271. [CrossRef] [PubMed]

11. Lattmann, E.; Ayuko, W.O.; Kinchinaton, D.; Langley, C.A.; Singh, H.; Karimi, L.; Tisdale, M.J. Synthesis and evaluation of 5 -arylated $2(5 H)$-furanones and 2-arylated pyridazin-3(2H)-ones as anti-cancer agents. J. Pharm. Pharmacol. 2003, 55, 1259-1265. [CrossRef] [PubMed]

12. Hamel, E.; Lin, C.M. Guanosine 5'-O-(3-thiotriphosphate), a potent nucleotide inhibitor of microtubule assembly. J. Biol. Chem. 1984, 259, 11060-11069. [PubMed]

13. Jha, K.K.; Samad, A.; Kumar, Y.; Shaharyar, M.; Khosa, R.L.; Jain, J.; Kumar, V.; Singh, P. Design, synthesis and biological evaluation of 1,3,4-oxadiazole derivatives. Eur. J. Med. Chem. 2010, 45, 4963-4967. [CrossRef] [PubMed]

14. Mamolo, M.G.; Falagiani, V.; Zampieri, D.; Vio, L.; Banfi, E.; Scialino, G. Synthesis and antimycobacterial activity of (3,4-diaryl-3H-thiazol-2-ylidene)-hydrazide derivatives. IL Farmaco 2003, 58, 631-637. [CrossRef]

15. Farshori, N.N.; Banday, M.R.; Ahmad, A.; Khan, A.U.; Rauf, A. Synthesis, characterization, and in vitro antimicrobial activities of 5-alkenyl/hydroxyalkenyl-2-phenylamine-1,3,4-oxadiazoles and thiadiazoles. Bioorg. Med. Chem. Lett. 2010, 20, 1933-1938. [CrossRef] [PubMed]

16. Yeung, K.-S.; Farkas, M.E.; Kadow, J.F.; Meanwell, N.A. A base-catalyzed, direct synthesis of 2,5-disubstituted 1,2,4-triazoles from nitriles and hydrazides. Tetrahedron Lett. 2005, 46, 3429-3432. [CrossRef]

17. Almajan, G.L.; Barbuceanu, S.-F.; Bancescu, G.; Saramet, I.; Saramet, G.; Draghici, C. Synthesis and antimicrobial evaluation of some fused heterocyclic [1,2,4]triazolo[3,4-b][1,3,4]thiadiazole derivatives. Eur. J. Med. Chem. 2010, 45, 6139-6146. [CrossRef] [PubMed]

18. Skoumbourdis, A.P.; Huang, R.; Southall, N.; Leister, W.; Guo, V.; Cho, M.-H.; Inglese, J.; Nirenberg, M.; Austin, C.P.; Xia, M.; et al. Identification of a potent new chemotype for the selective inhibition of PDE4. Bioorg. Med. Chem. Lett. 2008, 18, 1297-1303. [CrossRef] [PubMed]

19. Attanasi, O.A.; Filippone, P.; Perrulli, F.R.; Santeusanio, S. Regioselective role of the hydrazide moiety in the formation of complex pyrrole-pyrazole systems. Tetrahedron 2001, 57, 1387-1394. [CrossRef] 
20. Abdel-Aziz, M.; Abuo-Rahma, G.A.; Hassan, A.A. Synthesis of novel pyrazole derivatives and evaluation of their antidepressant and anticonvulsant activities. Eur. J. Med. Chem. 2009, 44, 3480-3487. [CrossRef] [PubMed]

21. Raddatz, S.; Mueller-Ibeler, J.; Kluge, J.; Wäss, L.; Burdinski, G.; Havens, J.R.; Onofrey, T.J.; Wang, D.; Schweitzer, M. Hydrazide oligonucleotides: New chemical modification for chip array attachment and conjugation. Nucleic Acids Res. 2002, 30, 4793-4802. [CrossRef] [PubMed]

22. Zhang, X.; Breslav, M.; Grimm, J.; Guan, K.; Huang, A.; Liu, F.; Maryanoff, C.A.; Palmer, D.; Patel, M.; Qian, Y.; et al. A new procedure for preparation of carboxylic acid hydrazides. J. Org. Chem. 2002, 67, 9471-9474. [CrossRef] [PubMed]

23. Saha, A.; Kumar, R.; Kumar, R.; Devakumar, C. Development and assessment of green synthesis of hydrazides. Indian J. Chem. 2010, 49, 526-531.

24. Aboul-Fadl, T.; Abdel-Aziz, H.A.; Kadi, A.; Bari, A.; Ahmad, P.; Al-Samani, T.; Ng, S.W. Microwave-assisted one-step synthesis of fenamic acid hydrazides from the corresponding acids. Molecules 2011, 16, 3544-3551. [CrossRef] [PubMed]

25. Marzouk, M.I. Microwave assisted reaction in synthesis of tetra- and hexa-cyclic spiro system. Bull. Chem. Commun. 2009, 41, 54-58.

26. Bondock, S.; EL-Tarhoni, A.E.G.; Fadda, A.A. Utility of cyanoacetic acid hydrazide in heterocyclic synthesis. Arkivoc 2006, 2006, 113-156. [CrossRef]

27. Marcos, M.; Dayse, N.M.; Clarissa, P.F.; Kelvis, L.; Nilo, Z.; Helio, G.B. Reaction of $\beta$-alkoxyvinyl halomethyl ketones with cyanoacetohydrazide. J. Braz. Chem. Soc. 2008, 19, 1361-1368.

28. Şerban, G. 5-Arylamino-1,3,4-thiadiazol-2-yl acetic acid esters as intermediates for the synthesis of new bisheterocyclic compounds. Farmacia 2015, 63, 146-149.

29. El-Emam, A.A.; Al-Deeb, O.A.; Al-Omar, M.; M. Lehmann, J. Synthesis, antimicrobial, and anti-HIV-1 activity of certain 5-(1-adamantyl)-2-substituted thio-1,3,4-oxadiazoles and 5-(1-adamntyl)-3-substituted aminomethyl-1,3,4-oxadiazoline-2-thiones. Bioorg. Med. Chem. 2004, 12, 5107-5113. [CrossRef] [PubMed]

30. Mohammed-Ali, M.A.; Majeed, N.N. Synthesis, characterization and study of antibacterial and antifungal activities of some 1,3,4-oxadiazole compounds. J. Chem. Pharm. Res. 2012, 4, 315-321.

31. Kumar, V.; Singh, S. Synthesis of some new 1,3,4-oxadiazole derivatives and evaluation of their antibacterial effects. J. Chem. Pharm. Res. 2012, 4, 546-553.

32. Sowjanya, C.; RamaBharathi, V.; Devi, G.K.; Rajitha, G. Synthesis and evaluation of some novel 3-[5-phenyl-1,3,4-oxadiazole- 2-yl]-2- (substituted styryl)-quinazoline-4(3H)-ones for antibacterial activity. J. Chem. Pharm. Res. 2011, 6, 212-216.

33. Sumangalaa, V.; Poojary, B.; Chidananda, N.; Arulmoli, T.; Shenoy, S. Synthesis, characterization, antimicrobial and antioxidant activity of some disubstituted [1,3,4]-oxadiazoles carrying 4-(methylsulfonyl/ sulfinyl)benzyl moieties. J. Chem. Pharm. Res. 2012, 4, 1661-1669.

34. Kucukguzel, S.G.; Oruc, E.E.; Rollas, S.; Sahin, F.; Ozbek, A. Synthesis, characterisation and biological activity of novel 4-thiazolidinones, 1,3,4-oxadiazoles and some related compounds. Eur. J. Med. Chem. 2002, 37, 197-206. [CrossRef]

35. Padmaja, A.; Rajasekhar, C.; Muralikrishna, A.; Padmavathi, V. Synthesis and antioxidant activity of disubstituted 1,3,4-oxadiazoles, 1,3,4-thiadiazoles and 1,2,4-triazoles. J. Chem. Pharm. Res. 2012, 4, $294-302$.

36. Kagthara, P.R.; Shah, N.S.; Doshi, R.K.; Parekh, H.H. Synthesis of 2,5-disubstituted 1,3,4-oxadiazoles as biologically active heterocycles. Ind. J. Chem. 1999, 38, 572-576.

37. Akhter, M.; Husain, A.; Azad, B.; Ajmal, M. Aroylpropionic acid based 2,5-disubstituted-1,3,4-oxadiazoles: Synthesis and their anti-inflammatory and analgesic activities. Eur. J. Med. Chem. 2009, 44, 2372-2378. [CrossRef] [PubMed]

38. Unangast, P.C.; Shrum, G.P.; Conner, D.T.; Dyer, C.D.; Schrier, D.J. Novel 1,2,4-oxadiazoles and 1,2,4-thiadiazoles as dual 5-lipoxygenase and cyclooxygenase inhibitors. J. Med. Chem. 1992, 35, 3691-3698.

39. Sing, A.K.; Parthsarthy, R.; Lohani, M. Synthesis, characterization and anti-inflammatory activity of some 1 , 3,4-oxadiazole derivatives. J. Chem. Pharm. Res. 2012, 4, 779-782.

40. Khan, M.S.; Khan, R.M.; Drabu, S. Anticonvulsant and antibacterial activity of some new 1,3,4-oxadiazole derivatives. Ind. J. Heterocycl. Chem. 2001, 11, 119-122.

41. O'Neal, J.B.; Rosen, H.; Russell, P.B.; Adams, A.C.; Blumenthal, A. Potential hypoglycemic agents: 1,3,4-Oxadiazoles and related compounds. J. Med. Chem. 1962, 5, 617-626. [CrossRef] 
42. Maslat, A.O.; Abussaud, M.; Tashtoush, H.; Al-Talib, M. Synthesis, antibacterial, antifungal and genotoxic activity of bis-1,3,4-oxadiazole derivatives. Pol. J. Pharmacol. 2002, 54, 55-59. [PubMed]

43. Farghaly, A.A.; Bekhit, A.A.; Park, J.Y. Design and synthesis of some oxadiazolyl, thiadiazolyl, thiazolidinyl, and thiazolyl derivatives of $1 H$-pyrazole as anti-inflammatory antimicrobial agents. Arch. Pharm. 2000, 333, 53-57. [CrossRef]

44. Savarino, A. A historical sketch of the discovery and development of HIV-1 integrase inhibitors. Expert Opin. Investig. Drugs 2006, 15, 1507-1522. [CrossRef] [PubMed]

45. James, N.D.; Growcott, J.W. Zibotentan. Drugs Future 2009, 34, 624-633. [CrossRef]

46. Bondock, S.; Adel, S.; Etman, H.A.; Badria, F.A. Synthesis and antitumor evaluation of some new 1,3,4-oxadiazole-based heterocycles. Eur. J. Med. Chem. 2012, 48, 192-199. [CrossRef] [PubMed]

47. Koparır, M.; Çetin, A.; Cansız, A. 5-Furan-2yl[1,3,4]oxadiazole-2-thiol, 5-furan-2yl-4H[1,2,4]triazole-3-thiol and their thiol-thione tautomerism. Molecules 2005, 10, 475-480. [CrossRef] [PubMed]

48. Amir, M.; Kumar, S. Synthesis and evaluation of anti-inflammatory, analgesic ulcerogenic and lipid peroxidation properties of ibuprofen derivatives. Acta Pharm. 2007, 57, 31-45. [CrossRef] [PubMed]

49. Mickevičius, V.; Vaickelionienè, R.; Sapijanskaitè, B. Synthesis of substituted 1,3,4-oxadiazolederivatives. Chem. Heterocycl. Comp. 2009, 45, 215-218. [CrossRef]

50. Martin, P.J.; Bruce, D.W. Hydrogen-bonded oxadiazole mesogens. Liq. Cryst. 2007, 34, 767-774. [CrossRef]

51. Hernández-Ainsa, S.; Barberá, J.; Marcos, M.; Serrano, J.L. Liquid crystalline ionic dendrimers containing luminescent oxadiazole moieties. Macromolecules 2012, 45, 1006-1015. [CrossRef]

52. Boström, J.; Hogner, A.; Llinàs, A.; Wellner, E.; Plowright, A.T. Oxadiazoles in medicinal chemistry. J. Med. Chem. 2012, 55, 1817-1830. [CrossRef] [PubMed]

53. Li, Z.; Zhu, A.; Mao, X.; Sun, X.; Gong, X. Silica-supported dichlorophosphate: A recoverable cyclodehydrant for the eco-friendly synthesis of 2,5-disubstituted 1,3,4-oxadiazoles under solvent-free and microwave irradiation conditions. J. Braz. Chem. Soc. 2008, 19, 1622-1626. [CrossRef]

54. Sharma, G.V.M.; Rakesh, B.A.; Krishna, P.R. Zirconium(IV) chloride mediated cyclodehydration of 1,2-diacylhydrazines: A convenient synthesis of 2,5-diaryl 1,3,4-oxadiazoles. Synth. Commun. 2004, 34, 2387-2391. [CrossRef]

55. Huisgen, R.; Szeimies, G.; Moebius, L. 1,3-Dipolar Cycloadditions. XXXII. Kinetics of the Addition of Organic Azides to Carbon-carbon Multiple Bonds. Chem. Ber. 1967, 100, 2494-2507. [CrossRef]

56. Baranov, A.B.; Tsypin, V.G.; Malin, A.S.; Laskin, B.M. Synthesis of 2-chloromethyl-5-aryl-, 2-chloromethyl-5-(5-methyl-2-furyl)-, and 2-chloromethyl-5-(1,5-dimethyl-2-pyrrolyl)-1,3,4-oxadiazoles from tetrazole derivatives. Russ. J. Appl. Chem. 2005, 78, 773-775. [CrossRef]

57. Efimova, Y.A.; Artamonova, T.V.; Koldobskii, G.I. Tetrazoles: LIII.* Microwave-activated acylation of 5-substituted tetrazoles. Russ. J. Org. Chem. 2008, 44, 1345-1347. [CrossRef]

58. Salem, M.A.; Marzouk, M.I.; Mahmoud, N.F. Synthesis of various fused pyrimidine rings and their pharmacological and antimicrobial evaluation. J. Serbian Chem. Soc. 2014, 79, 1059-1073.

59. Salem, M.A.I.; Marzouk, M.I.; Salem, M.S.; Alshibani, G.A. One-pot Synthesis of 1,2,3,4-tetrahydropyrimidin-2(1H)-thione derivatives and their biological activity. J. Heterocycl. Chem. 2015. [CrossRef]

60. Salem, M.A.I.; Marzouk, M.I.; Mashaly, H.M. Synthesis of pharmacological dyes and their application on synthetic fabrics. Color. Technol. 2015, 131, 288-297. [CrossRef]

61. Salem, M.A.I.; Marzouk, M.I.; Gaffer, H.E. Synthesis of 4-hydroxy coumarin dyes and their applications. Pigment Resin Technol. 2016, 45. in press.

62. Marzouk, M.I.; Shaker, S.A.; Abdel-Hafiz, A.A.; El-Baghdady, K.Z. Design and synthesis of new phthalazinone derivatives containing benzyl moiety with anticipated antitumor activity. Biol. Pharm. Bull. 2016, 39. in press.

63. El-Hashash, M.A.; Guirguis, D.B.; Kadhim, M.A. Synthesis and reaction of 2-(1-oxo4(1,2,3,4-tetrahydronaphthalen-2-yl)phthalazin-1(2H)-yl)acetohydrazide. J. Am. Sc. 2013, 9, 180-185.

64. Mohammed, A.A.; Abdelwahed, R.S.; Magdy, M.Y. Synthesis of novel triazoles, tetrazine, thiadiazoles and their biological activities. Molecules 2015, 20, 2591-2610.

65. Liu, X.; Guo, Y.; Li, Y.; Jiang, Y.; Chubb, S.; Azuma, A.; Huang, P.; Matsuda, A.; Hittelman, W.; Plunkett, W. Molecular basis for G2 arrest induced by 2 '-C-cyano-2'-deoxy-1- $\beta$-D-arabino-pentofuran osylcytosine and consequences of checkpoint abrogation. Cancer Res. 2005, 65, 6874-6881. [CrossRef] [PubMed] 
66. Avendaño, C.; Menendez, J.C. Medicinal Chemistry of Anticancer Drugs, 2nd ed.; Elsevier: Amsterdam, The Netherlands, 2015; pp. 73-74.

67. Gutteridge, J.M.; Rowley, D.A.; Halliwell, B. Superoxide-dependent formation of hydroxyl radicals in the presence of iron salts. Detection of "free" iron in biological systems by using bleomycin-dependent degradation of DNA. Biochem. J. 1981, 199, 263-265. [CrossRef] [PubMed]

68. Mosmann, T. Rapid colorimetric assay for cellular growth and survival: Application to proliferation and cytotoxicity assays. J. Immunol. Methods 1983, 65, 55. [CrossRef]

69. Denizot, F.; Lang, R. Rapid colorimetric assay for cell growth and survival. J. Immunol. Methods 1986, 89, 271-277. [CrossRef]

70. Mauceri, H.J.; Hanna, N.N.; Beckett, M.A.; Gorski, D.H.; Staba, M.; Stellato, K.A.; Bigelow, K.; Heimann, R.; Gately, S.; Dhanabal, M.; et al. Combined effects of angiostatin and ionizing radiation in antitumour therapy. Nature 1998, 394, 287-291. [PubMed]

71. Lissi, E.A.; Modak, B.; Torres, R.; Escobar, J.; Urzua, A. Total antioxidant potential of resinous exudates from Heliotropium species, and a comparison of the ABTS and DPPH methods. Free Radic. Res. 1999, 30, 471-477. [CrossRef] [PubMed]

72. El-Gazar, A.B.A.; Youssef, M.M.; Youssef, A.M.S.; Abu-Hashem, A.A.; Badria, F.A. Design and synthesis of azolopyrimidoquinolines, pyrimidoquinazolines as anti-oxidant, anti-inflammatory and analgesic activities. Eur. J. Med. Chem. 2009, 44, 609-624. [CrossRef] [PubMed]

73. Aeschlach, R.; Loliger, J.; Scott, B.C.; Murcia, A.; Butler, J.; Halliwell, B.; Aruoma, O.I. Antioxidant actions of thymol, carvacrol, 6-gingerol, zingerone and hydroxytyrosol. Food Chem. Toxicol. 1994, 32, 31-36. [CrossRef]

74. Bakr, F.A.; Abdel-aziz, S.E.; Farid, A.B. Synthesis of new 2-naphthyl ethers and their protective activities against DNA damage induced by Bleomycin-Iron. Chem. Pharm. Bull. 2009, 57, 1348-1351.

75. Badria, F.A.; Ameen, M.; Akl, M.R. Evaluation of cytotoxic compounds from Calligonum comosum L. growing in Egypt. Z. Naturforsch. C 2007, 62, 656-660. [CrossRef] [PubMed]

Sample Availability: Not available.

(C) 2016 by the authors; licensee MDPI, Basel, Switzerland. This article is an open access article distributed under the terms and conditions of the Creative Commons by Attribution (CC-BY) license (http://creativecommons.org/licenses/by/4.0/). 